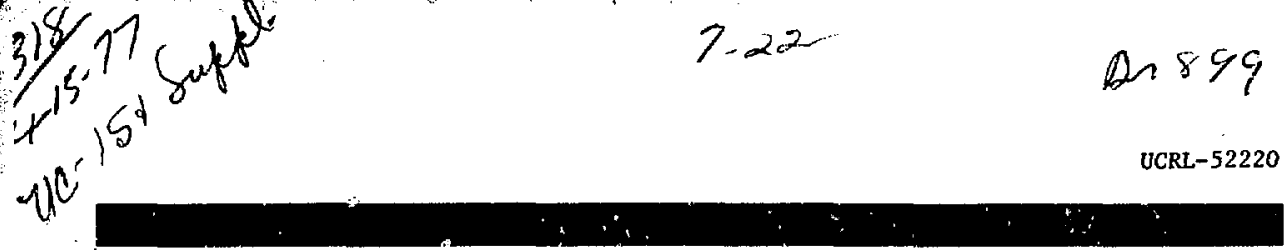

\title{
IN-LINE MEASUREMENT OF TOTAL AND ISOTOPIC PLUTONIUM CONCENTRATIONS BY GAMMA-RAY SPECTROMETRY
}

R. Gunnink and J. E. Evans

February 7, 1977

Prepared for U.S Energy Research \& Development

Administration under contract No. W-7405-Eng-48

\section{IL LAWRENCE LIVERMORE LABORATORY \\ Urhersifyor Callomia, Livermore}

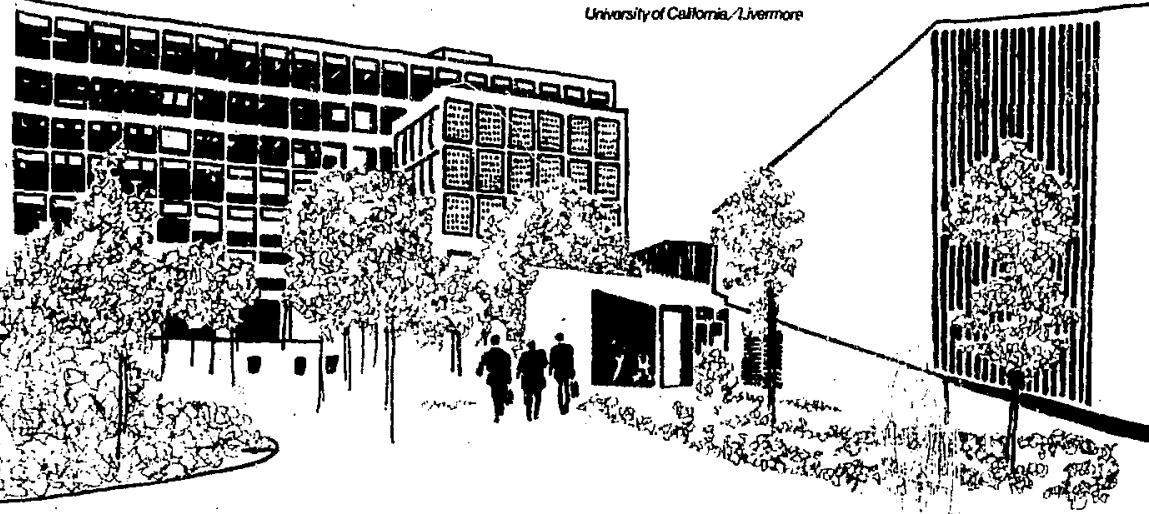

4

MAs 


\section{NOTCE}

This report we plopared an sccount of work sponsorcd by the Uniled Sutes Gowernment. Neither the Unlted Sutes nor the United States Enery Rextrch a Dewlopitent Admintration, not iny of that emiployeas, not any of thetr contractora, abcontrectors. q their emplayses, mikes ony wamanty, exprea a implad, of axumes any lesal bablity to reporability for the aceuncy, completeneat of unefulness of any information, eppatetter, product of procest diclawed, or represents that is us would not infrings privatelyownod ifins.

\section{NOTICE}

Referenco to company or product name does tot inply approval or recomanendation of the product by the Untretrity of Culliornil or the U.S. Energy Resarch a Daviopment Administration to the exclusion of otheri that may be wituble.

Printed in the United States of Americo Avalibble from

National Technical information Service

U.S. Depariment of Conmerse

S285 Port: Royal Road

Spingfieid, VA 2216t

Prict: Printed Copy $\mathbf{S}$ : Microliche $\mathbf{\$ 3 . 0 0}$

\begin{tabular}{|c|c|c|c|c|}
\hline$P_{\text {eq }}$ Ronst & $\begin{array}{c}\text { Dometi } \\
\text { Price }\end{array}$ & & Pes Fenge & $\begin{array}{l}\text { Domatk } \\
\text { Pritep }\end{array}$ \\
\hline $001-025$ & $\$ 3.50$ & & $326-350$ & 10.00 \\
\hline $026-050$ & 4.00 & & $351--375$ & 10.50 \\
\hline $05 t-075$ & 4.50 & - & $376-400$ & 10.75 \\
\hline $076-100$ & $\quad 5.00$ & & $401-425$ & 11.00 \\
\hline $101-125$ & 5.50 & & $426-450$ & 11.75 \\
\hline $126-150$ & 6.00 & & $4 \leq 1-475$ & 12.00 \\
\hline $151-175$ & 6.75 & & $426 \cdot-500$ & 12.50 \\
\hline $176-200$ & 7.50 & & $501-525$ & 12,75 \\
\hline $201-275$ & 7.75 & & $526-550$ & 13.00 \\
\hline $226-\div 50$ & 8.00 & & $55\}-575$ & 13.50 \\
\hline $251-275$ & 9.00 & & $576-600$ & 13.75 \\
\hline $276-300$ & 9.25 & & $601-u p$ & $\bullet$ \\
\hline $301-325$ & 9.75 & & & \\
\hline
\end{tabular}

Adj \$2.50 for each edditonal 100 page inctement from 601 to 1,000 papda; add 4,50 fot ench addisonal 100 page incement over 1,000 pages. 


\section{近 \\ LAWRENCE LIVERMORE LABORATORY \\ University ol Cattomia Livermore, Calitornia 94550}

UCRL-52220

\section{IN-LINE MEASUREMENT OF TOTAL AND ISOTOPIC PLUTONIUM CONCENTRATIONS BY GAMMA-RAY SPECTROMETRY}

R. Gunnink and J. E. Evans

MS. Date: February 7, 1977

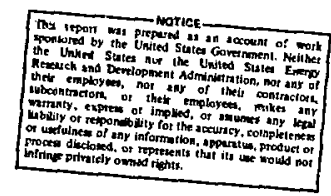

DSTRIBUTION OF THIS DOC!" ENT IS UNLTMITED 


\section{Contents}

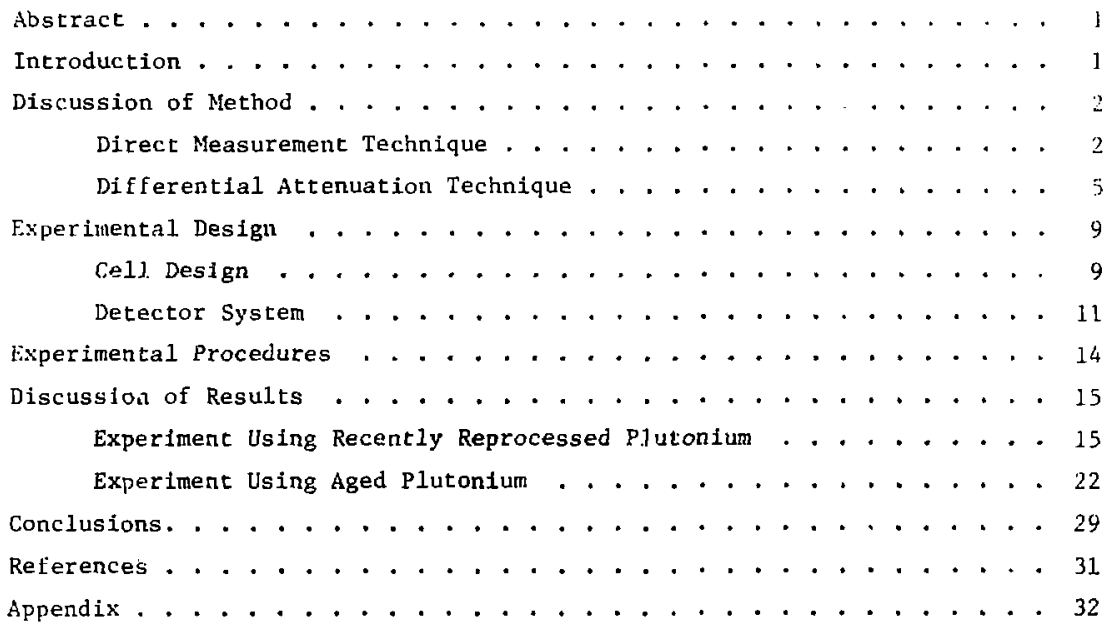




\title{
IN-LINE MEASUREMENT OF TOTAL AND ISOTOPIC PLUTONIUM CONCENTRATIONS BY GAMMA-RAY SPECTROMETRY
}

\begin{abstract}
This report describes preliminary experiments studying the feastbllity of gamma-ray spectrometry for in-11ne measurements of plutonium in solutions. We measured the isotopic content of the plutonium by direct counting and the total plutonium
content by a differential attenuation technjaile. Two separato experiments on different solutions were performed with each technique. Our results show that both isotopic and total measurements can be made with pre- cistons around 0.25 to $0.5 \%$.

\section{Introduction}

Ganma-ray spectrometry methods have previously provided accurate assays of plutonium concentrations in solutions. Our objectives in the experiments described in this progress report were to investigate the feasibility of these techniques for 1n-1ine analyses of both total and isotopic plutonium content.

In-line analyses might be used in plutonium load-out accountability tanks and in the storage tanks of reprocessing facilitles. Since gamma-ray spectrometry methods are nondestructive and can be automated and controlled by computers, these techniques could be used to analyze and Inventory the tanks on a more timely basis without breaching the containment of the plutontum, thus
Increasing plant operation efficiency whtle safeguarding the plutonium.

To assess the possibility of inline plutonium assays, we designed an experimental configuration using two cells. One cell measured the plutonium 1sotopes directly by gamma-ray detection. The other cell measured total plutonium concentration by differentially attenuating two transmitted gamma rays whose energles were on either side of the K-shell bitiling energy for plutonium. The purpose of our experiments was to initially assess the accuracy with which isotopic and total plutonium analyses could be made on process streams, to determine the optimum values for the various experimental parameters, and to determine the IImitations and 
problems associnted with the

neasuitments.

We condicted two separate experiments, the iirst on concentrated plutonium tistrate solution from which tine ${ }^{241} \mathrm{Am}$ and $\because 3 \%$ Pu had been chemically removed (simulating the solution found in the product load-out area uf a reprocessing pliant), and the second on a solution that simulated an "aged" plutoniun solution (as would be found in storage areas). our results indicate that both isotopic and total measurements can be made with precisions in the range of 0.25 to $0.5 \%$.

\section{Discussion of Method}

Our experimental design called for a direct measurement of gamma rays emitted by the plutonium in the solution and a separate measurement of two closely spaced gamna rays at $122 \mathrm{keV}$ that had been transmitted through the solution.

\section{DIRECT MEASUREMENT TECHNIQUE}

The isotopes of interest in a plutonium solution are ${ }^{238} \mathrm{Pu},{ }^{239} \mathrm{Pu}$, ${ }^{240} \mathrm{Pu},{ }^{241} \mathrm{Pu},{ }^{242} \mathrm{Pu}$ and ${ }^{241} \mathrm{Am} .{ }^{23} j_{\mathrm{U}}$ 1s also present as a daughter product of ${ }^{241}$ tu. of these, ${ }^{242} \mathrm{Pu}$ cannot be observed in the gamma spectrum and therefore cannot be measured by direct counting. The others all emit sufficiently abundant gamma rays to be detected using germanium detector systems.

The gamma-ray energies and 1atensities for these isotopes have been carefully characterized. $1,2,3$ These data are useful for designing spectroscopic procedures since different procedures, or at least variations of them, are required depending on the rype of matorial to be analyzed. For example, the low-energy spectra of recently processed plutonium (Fig. 1) are considerably different from spectra of the same material after 1 t has been aliowed to age (Fig. 2). As a result, the experimental counting arrangement should be tailored for the spectific sample, and separate analysis programs must be written to incerpret the spectra.

A general discussion of the spectral features and our approach to computer reduction of the data has been given In an earlier report. ${ }^{4}$ Although we have made several procedural improvements since the initial report, our discussions will emphasize experimental design and results, not details of methodology. However, we give here a brief review and discussions of some significant problems not described in earlier reports. 


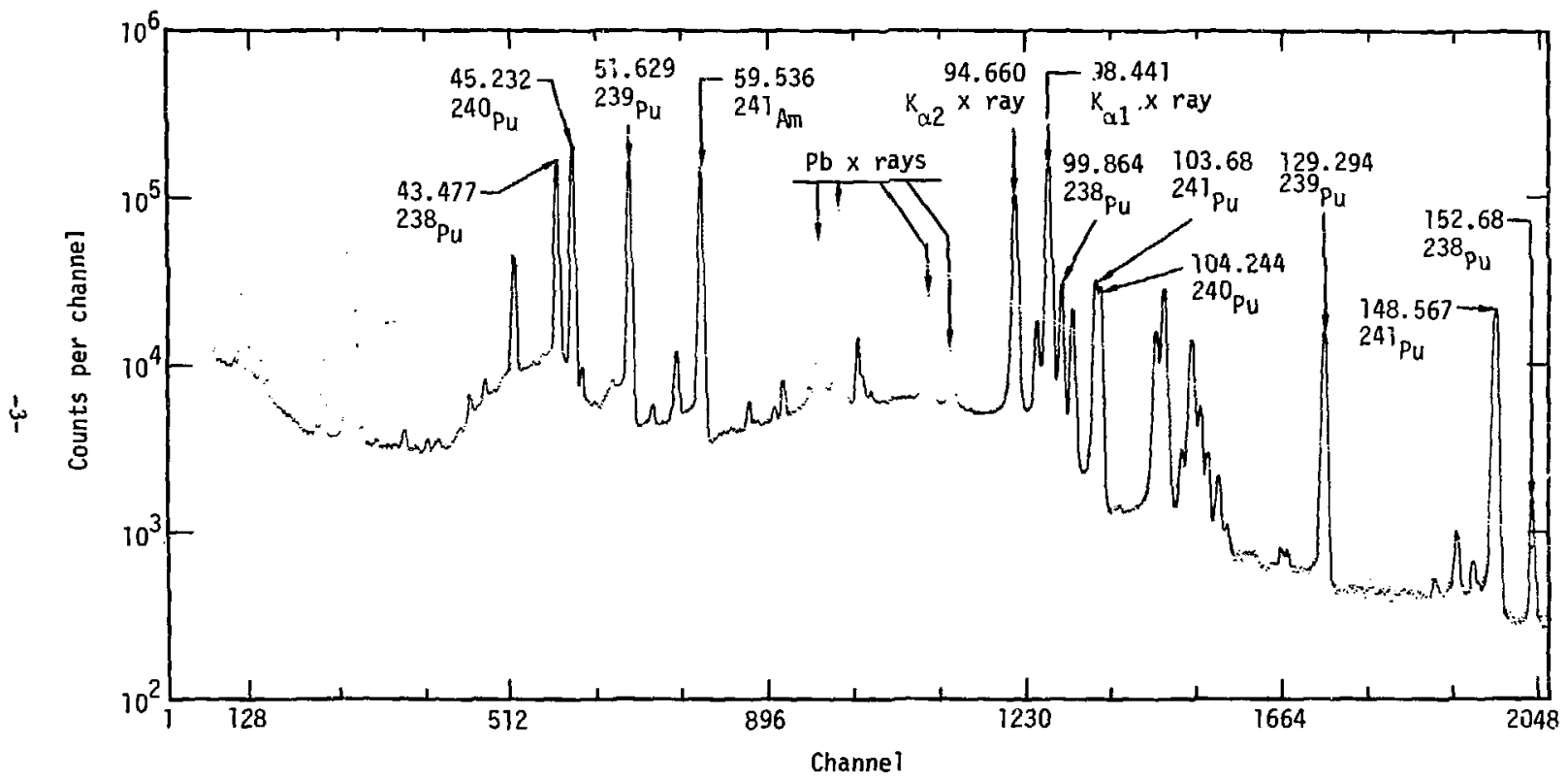

Fig. 1. Low-energy spectrum of recently separated reacter-grade plutonium solution. 


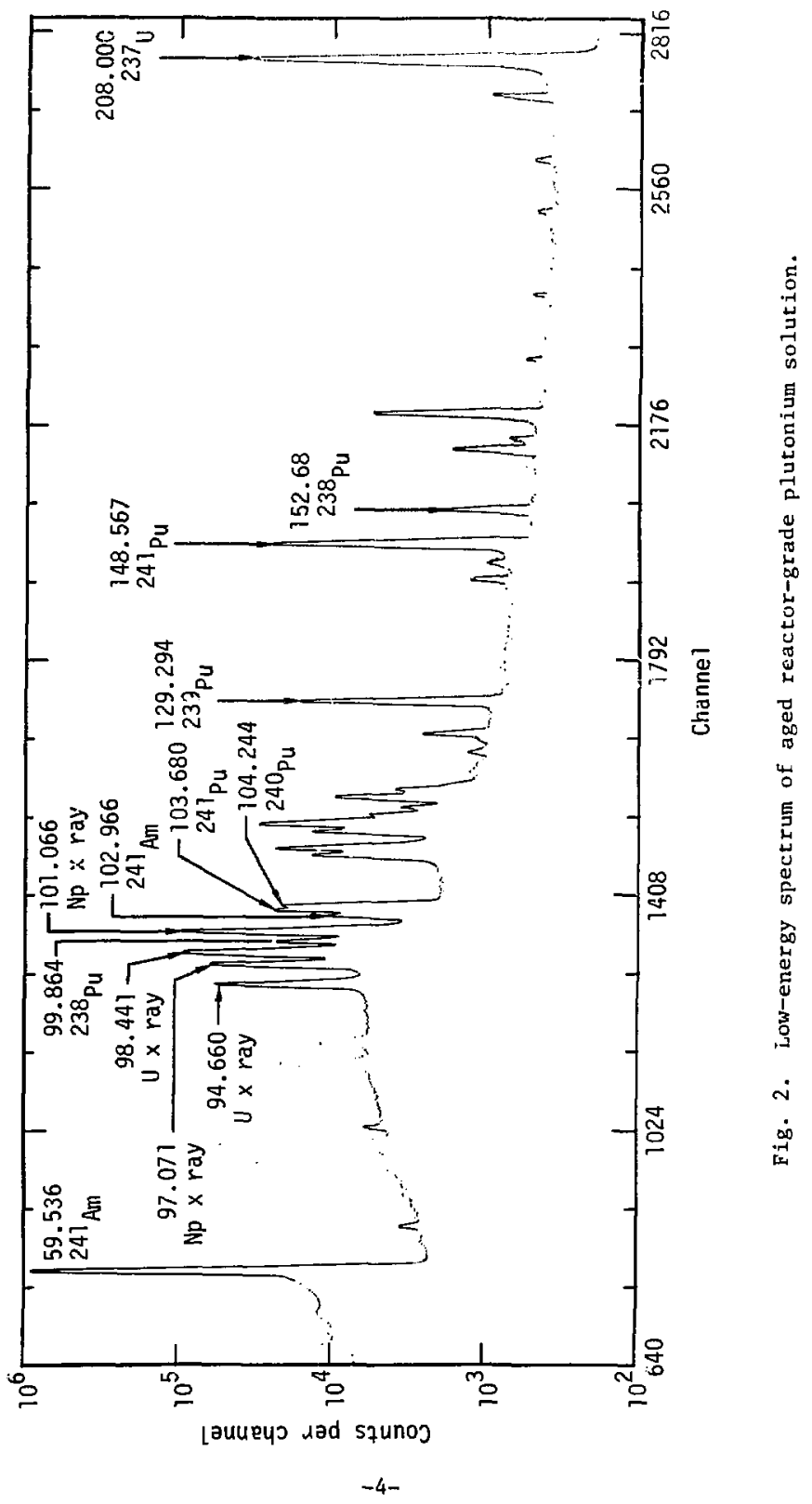


All of our analyses were made on the low-energy (below $210 \mathrm{keV}$ ) portion of the spectra. Table I summarizes the peaks in this region that are most prominent and amerable to interpretation. Recently processed solutions exhtbit several intease peaks from which we can deduce isotopic abundances (see Fig. 1), Our procedure is to use the 43-keV peak for a measurement of ${ }^{238} \mathrm{Pu}$, the $51-\mathrm{keV}$ peak for ${ }^{239} \mathrm{Pu}$, the $45-\mathrm{keV}$ peak for $240 \mathrm{Pu}$, and the $148-\mathrm{keV}$ peak for ${ }^{241} \mathrm{Pu}$. We also analyzed the $94-\mathrm{keV}$ and $129-\mathrm{keV}$ peaks to confirm the results for ${ }^{241} \mathrm{Pu}$ and ${ }^{239} \mathrm{Pu}$, respectively. The computer analvsis is quite straightforward, but accurate results require some attention to details. For example, the analysis of 43- to 45-keV peaks requires removal of small interferences due to ${ }^{239} \mathrm{pu}$ and ${ }^{241} \mathrm{pu}$ peaks in the vicinity. 3

Although the counting cell had a thickness of only $1 \mathrm{~mm}$, significant attenuations of the gamma rays occurred in the sample. This is due to the high concentrations of plutonium in the solution (200-300 g/1itre) and the high attenuation coefflcient that plutonium has for low-energy gamma rays. Without knowing a priori the concentration of the plutonium, we cannot $r$ igorously compute the attenuation that has occurred. Instead, an iterative approach must be ustid, startfng with an approximate measure of the concentration. Our procedure for this is detailed in the Appendix.

Aged filutonium is generally characterized by the presence of ${ }^{237} \mathrm{~V}$ and 241 Am resulting from the decay of $241_{\text {l'u. The concomitant } 59-k e V \text { peak }}$ of ${ }^{241} \mathrm{Am}$ is quite intense and obscures the spectral feacures of lower energy. We therefore analyze higher energy peaks which must now include the complex $94-$ to $104-\mathrm{kev}$ peak multiplet shown in Fig. 3 to get good measurements for ${ }^{238} \mathrm{Pu}$ and 240 Pu. This peak grouping consists of up to $14 x$ rays and gamna rays. However, since $x$ rays of this energy have a significant intrinsic line widh (about $100 \mathrm{eV}$ ), the observed peak shape distribution is noticeably different from that of a gamma-ray peak of equivalent energy ${ }^{5,6}$ (see Fig. 4). We made considerable effort to develop an algorithm that would adequately describe the shape of $x$-ray jeaks. A description of the problem and its mathematical solutions are treated in a separate report. ${ }^{7}$

\section{DIFFERENTIAL ATTENUATION TECHNIQUE}

The principle underlying this technique is simply that the transmisston, $T$, of a gamma ray by a material is related to 1 ) the amount. of the material present, $x$, and 2) the absorption coeificient, $\mu$, of the 
Table 1. Prominent low-energy gama rays associated with isotopes of plukmitum and $241_{\mathrm{Am}}$ and the corresponding emission probabilities.

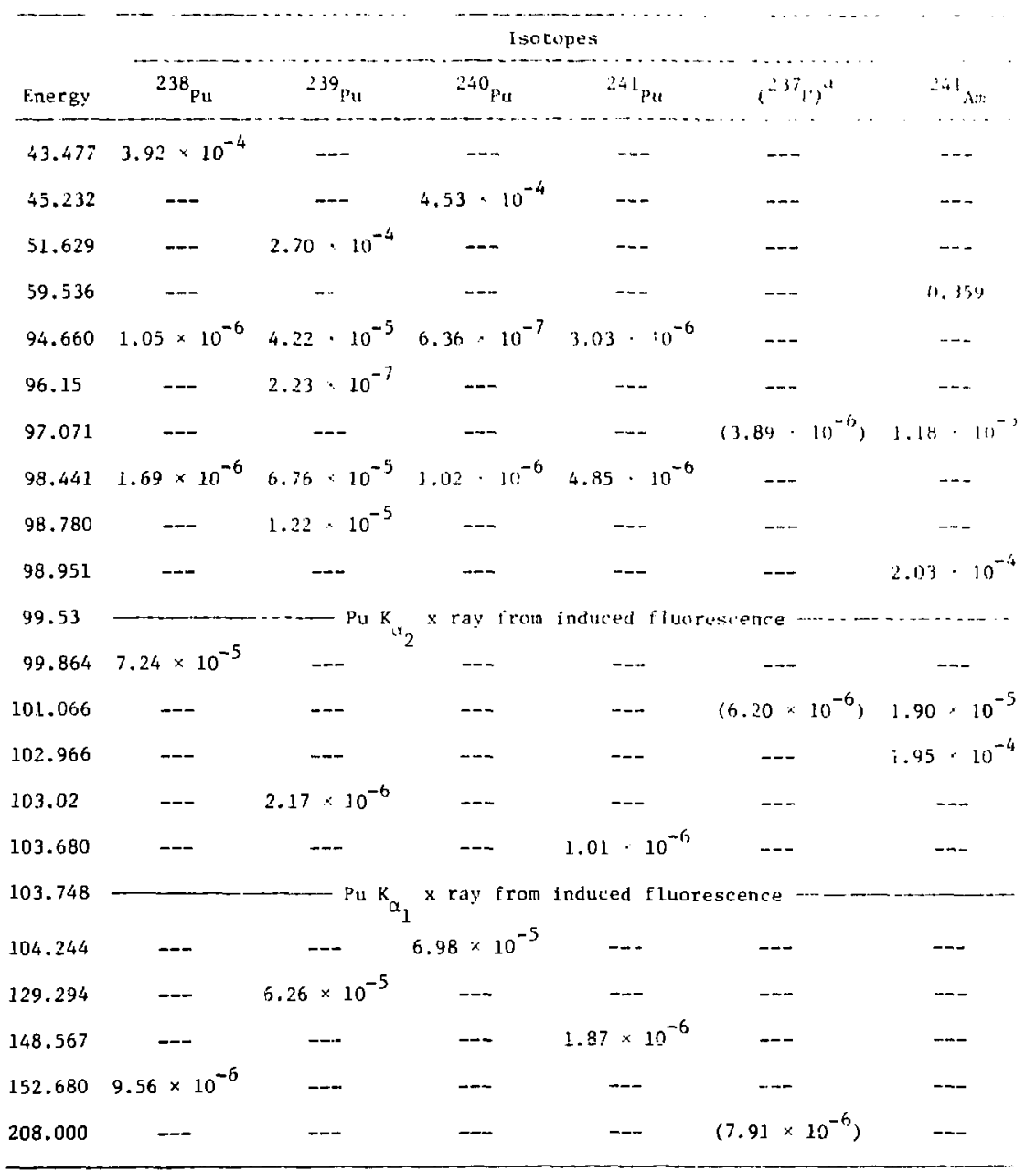

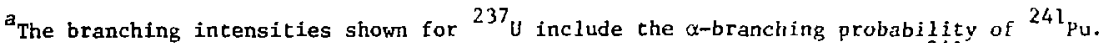
The values therefore represent photon emission probability per decay of $241_{\mathrm{Pu}}$, assuning a decay equilibrium has been established. 


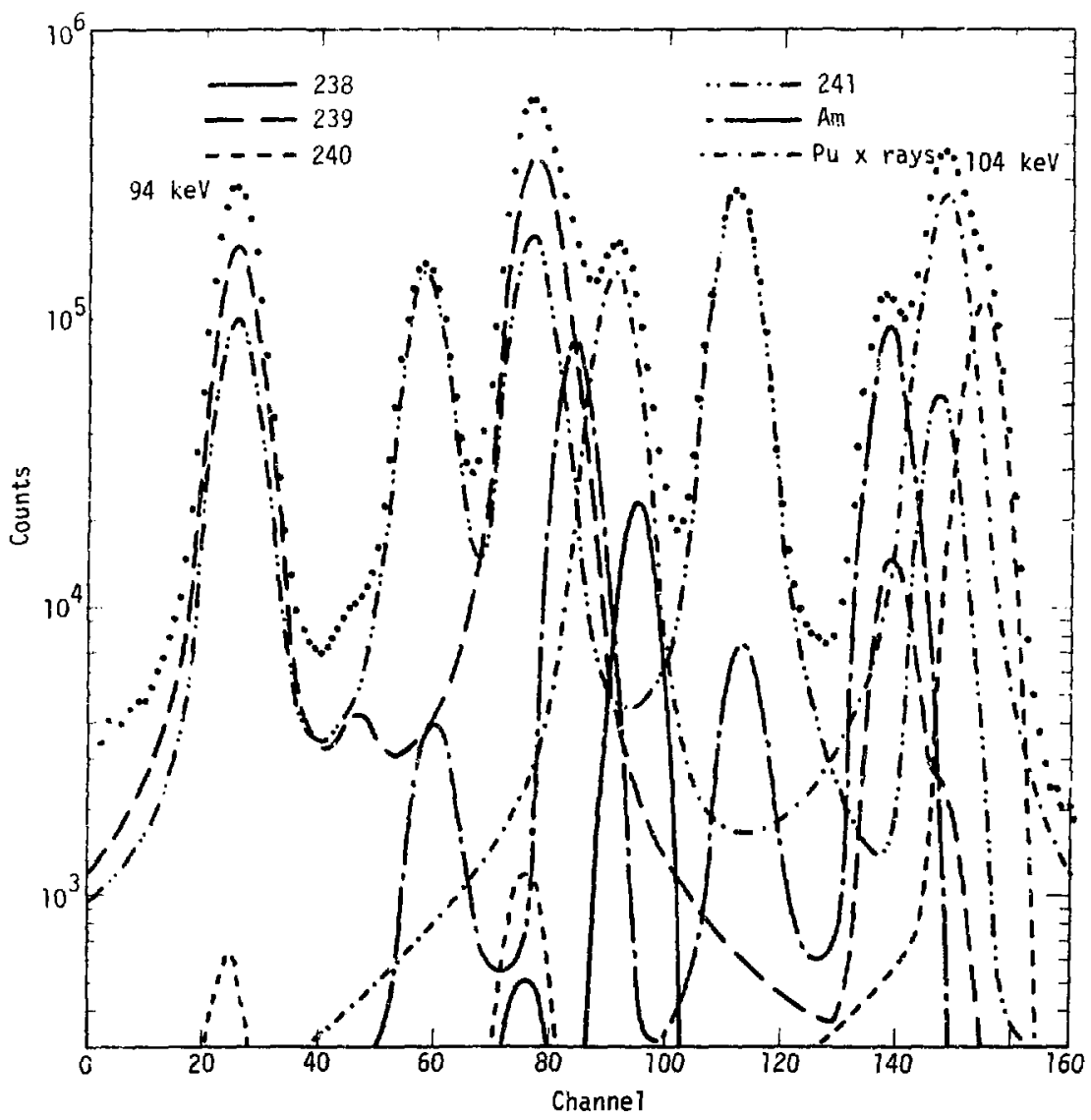

Fig. 3. The 94- to 104-keV peak multiplet of a weapuns-grade Pu oxide sample. This is a very complex region, consisting of up to $14 x$ rays and gamma rays that must be interpreted for the isotopic analysis of aged plutoritum samples. For solutions, the. $P u$ x-ray contribution from $\alpha$-induced fluorescence will be substantially less than is shown here. 


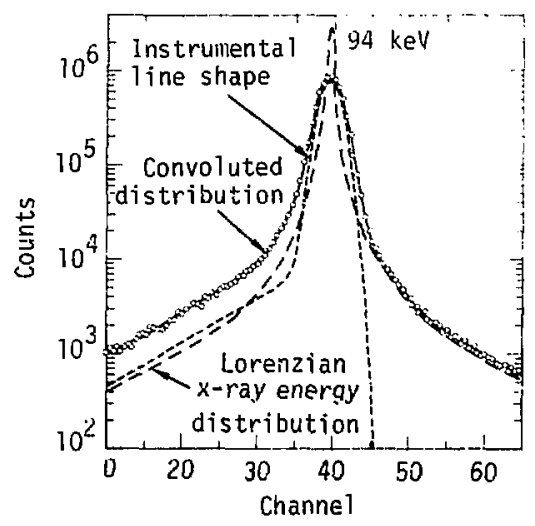

FIg. 4. The Lorentzian $x$-ray energy distribution contined with the Gaussian shaped curve for instrumental broadening result in the convoluced distribution line shown. The modified peak shape which results differs from that of a gamma ray of equivalent energy.

material. The relationship is expressed by

$$
T=I / I_{0}=\exp [-\mu \cdot x]
$$

where $I_{0}$ and $I$ are the initial and final intensltles and $\mu$ and $x$ are expressed in units that are the reciprocal of each other.

If the absorption coefficient $\mu$ is known and the reduction of latensity of a gamma ray $\left(I / I_{0}\right)$ can be measured, then the concentration, $x$, can be calculated.

For composite materials, the total. attenuation is glven by the same expression except that $j \cdot x$ now can be considered to be the sum ai its compoment elements, tha! is

$$
(\mu \cdot x)_{\text {total }}=\sum_{\mu_{i}} \cdot x_{i} .
$$

In principle, one additional constituent can now be determined for every coditional gamna-ray intensity ratio that is measured with a corresponding knowledga of the appropriate ausorption coeffictent. In practice, the technique is limited to measuring the concentration of a heavy element in a low-z matrix. This is done by observing the reduction in intensity of two transmitted gamma rays, one al low energy where the dirferences in absorbance between low- and high-z materials are large and the other at higher energy where the aisorption coeficients are similar. This approach, using $60 \mathrm{keV}$ from ${ }^{241} \mathrm{Am}$ and $662 \mathrm{keV}$ from ${ }^{137} \mathrm{Cs}$, has been the basis of systems developed by F. Cartan ${ }^{8}$ for plutonium analysis in product streams. The technique cannot, however, distinguish plutonium from other heavy elements such as uranium.

An alternative to the above procedure was first reported by Canada et a1. 9 This approach takes advantage of the abrupt discontinuity in the absorbancy that occurs at the K-shell binding energy of an element for plutonium, at $121.80 \mathrm{keV}$. Normally, two gamma rays of nearly equal energy are attenuated to the same extent because the differonces in the 
absorption coefficients at the two energies are nearly equal. However. ganma rays of energies just below and above the $\mathrm{K}$-shell binding energy of an element show considerably different rates of attenuation.

We can take arivantage of this phenomenon in the assay of plutonium solution. The solution can be considered to be a two-component system described wimply as a concentration of plutonfum in some other generally (though not necessarily) low-z material. The ratio of the transmission for the two gamma rays, $\Sigma_{1}$ and $E_{2}$, is given by

$$
\begin{gathered}
T_{I} / T_{2}=\exp \left[-\left(1_{\mu_{\mathrm{Pu}}}-{ }^{2} \mu_{\mathrm{Pu}}\right) \cdot \mathrm{x}_{\mathrm{Pu}}\right] \\
\cdot \exp \left[-\left(1_{\mu_{\mathrm{m}}}-{ }^{2} \mu_{\mathrm{m}}\right) \cdot \mathrm{x}_{\mathrm{m}}\right]
\end{gathered}
$$

Since ${ }^{1} \mu_{m}$ and ${ }^{2} \mu_{m}$ for the matrix are nearly the same, the last exponential term in the equation approaches unity. As a result, the logarithm of the transmission ratio is Iinearly related to the plutonium concentration,

$\ln \left(\mathrm{T}_{1} / \mathrm{T}_{2}\right)=-\left({ }^{1} \mu_{\mathrm{Pu}}-{ }^{2} \mu_{\mathrm{Pu}}\right) \cdot x_{\mathrm{Pu}} \cdot$

Experimentajly, two gamma rays must be found that have energies slightly below and above $121.80 \mathrm{keV}$ and that have sufficlent energy separation so that they are at least partially resolved by a high-resolution germanium gamma-ray spectroneter. One pair of Isotopes suggested by Canada et al. 9 satisfying these criteria $1{ }^{75} \mathrm{Se}$ and ${ }^{57} \mathrm{Co}$. We used these isotopes, which emit gamma rays at 121.05 and $122.05 \mathrm{kev}$, respectively, in our experiments.

\section{Experimental Design}

Since ane of the objectives of the experiments was to simulate on-1ine measurements of plutonium in process streans, a small flow system was buflt and set up in a glove box as shown in Fig. 5. A horizontally mounted germanium detector was located outside the box and viewed the cells through a rubber diaphragm mounted in one of the ports of the glove box. 'ihe remaining part of the system was a computer-based gamma spectrometer system which was used to acquire and interpret the spectra (see FIg. 6).

CELL DESIGN

Since two types of measurements were required, a configuration containing two cells was designed. The cells were made of quartz glass and connected with tubing. The solution 


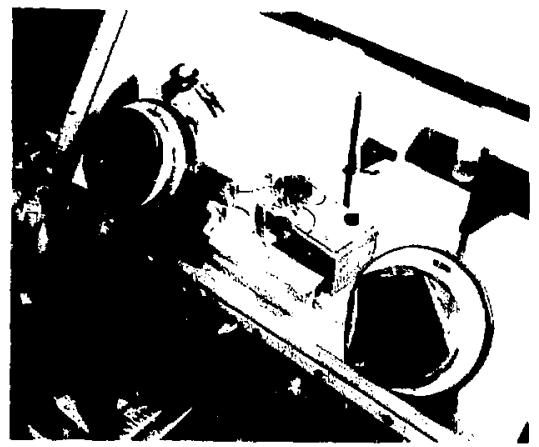

Fig, 5. Photograph of the experimental arrangement in the glove box. The detectur is located outside of the box at the left side of the figure.

was circulated through the celle and the dilution reservoir by a peristaltic pump.

The direct counting cell was placed closest to the detector and had a volume of 0.3 millilitres and an inside thickness of $0.11 \mathrm{~cm}$. The transmission cell had a diameter of
$0.8 \mathrm{~cm} \mathrm{1.d.} \mathrm{and} \mathrm{was} 3.57 \mathrm{~cm}$ long. An approximate length between 3 and $4 \mathrm{~cm}$ was arrived at by cortsidering two competing parameters of the transmission measurement. One was the sensitivity of change in peak height ratio to change in plutonium concentration (dR/dC increases with concentration as shown in Fig. 7). The other was the limited range for which accurate peak helght ratios can be measured, which linits the concentration range that can be assayed. We chose to conduct ont experiments in the 150to $300-\mathrm{g} / 11$ tre concentration range with a sensitivity of about 2 to $3 \%$ change in peak hefght ratio far a $1 \%$ change in concentzuition.

We also needed to design $\exists$ shutter that would selectively discriminate between the cells. The configuration is schematically shown in Fig. 8; a picture of the partiaj.ly assembled

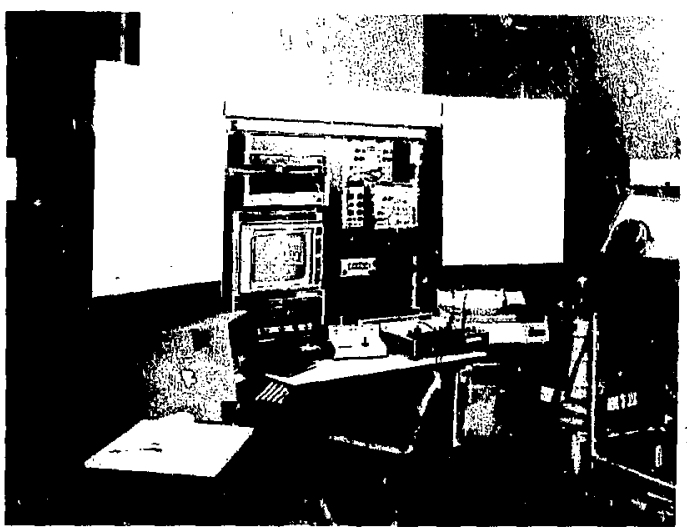

Fig. 6. Computer-based gamma spectrometer used for acquiring and reducing the spectral data. 
Pu coricentration (g/litre) in celi $3.5 \mathrm{cml}$ long

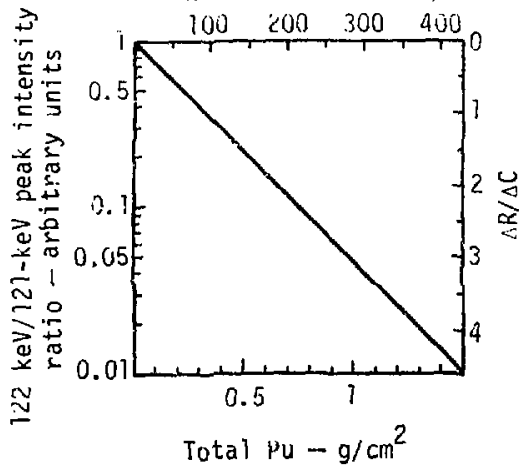

Fig. 3. The plutonium concentration is Iinearly related to the logarithm of the $122 ; 121-\mathrm{keV}$ peak intensity ratios. The sensitivity, $\triangle R / L C$, increases with tatal plutonium content.

apparatus is shown in Fig. 9. In the first position, the detector views the entire area of the small thin cell but is shielded from all other sources of radiation. A spectrum taken in this configuration provides data on the isotopic content of the solution by direct counting of the solution. Tn the second position, the viewing aperture for the small cell is reduced to a $0.5-\mathrm{cm}$ diameter, and a collimating port of the same dimension is opened to the transmission cell. In this mode, the total gamma radiation level from the source is reduced by the collimation to enhance the measurement of the two transmission gamma rays. A $0.6-\mathrm{g} / \mathrm{cm}^{2}$
Cd absorber was used in front of the detector to further reduce low-energy raciation originating in the solution. the ${ }^{75} \mathrm{Se}-{ }^{57} \mathrm{Co}$ source for the transmission gamma rays contained approximately $0.4 \mathrm{mCi}$ of ${ }^{75} \mathrm{Se}$ and $1.6 \mathrm{mCi}$ of ${ }^{5 i} \mathrm{Co}$. The gamma rays from the source were directed toward the transmission cell and detector by a $0.5-\mathrm{cm}$-diameter collimation hole in the lead shield surrounding the source. DETECTOR SYSTEM

The gamna-ray system constsced of a small, high-resolution Ge detectar and a computer-based pulse height analyzer. The detector was about $1 \mathrm{~cm}^{3}$ in volume and had a resolution of $530 \mathrm{eV}$ FWH at $122 \mathrm{keV}$. The system was operated with a shaping time constant of $6 \mu$ s and $a$ gain of $0.075 \mathrm{keV}$ per channel. The pulse height distribution was accumulated In 4096 channels. is pulse height stabilizer was useci to minimize zero and gain shifts, and a Camberra model 1468 livetime corrector/pileup rejector was also incorporated to improve the performance of the system. The measured livetime error as a function of count rate is shown in Fig. 10. The count rate in the experiments did not exceed 14000 counts per second. At tîis count rate, the resolution deteriorated to $545 \mathrm{eV}$ FWHM. These sinall changes in resolution are accounted for in the analysis programs. 


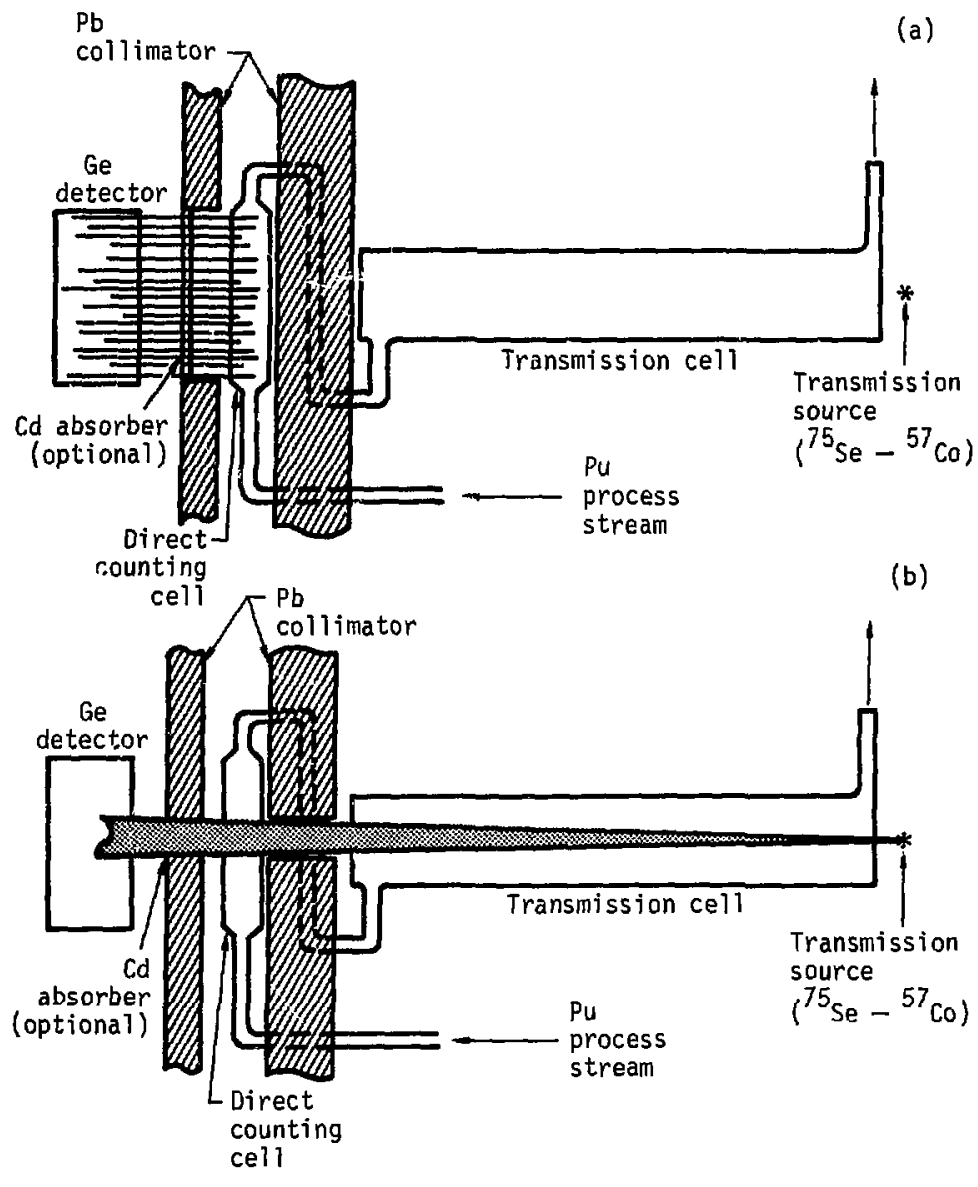

Fig. 8. Schematic of the experimental arrangement. (a) shows the direct counting configuration and (b) shows the configuration for the transmission measurement. 


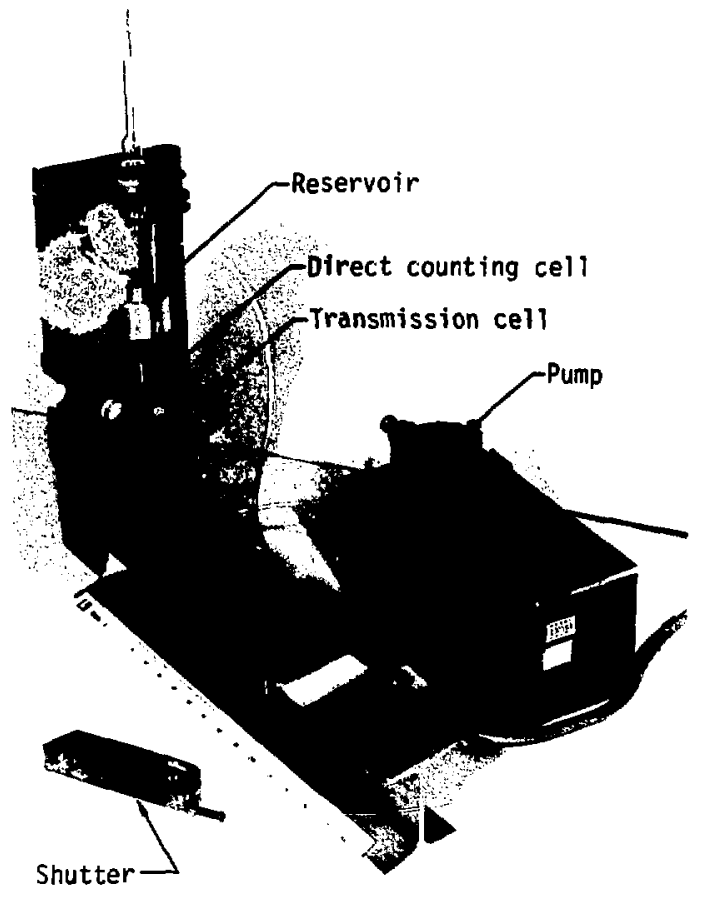

F1g. 9. Photograph of the component parts of the experimental arrangement. The solution is loaded into the mixing reservoir and pumped through the two counting cells. The lead shutter different1ates between the two counting arrangenents.

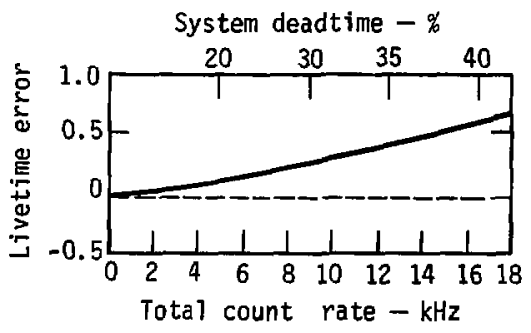

FIg. 10. System error in measuring the true IIvetime of a count as a function of count rate. 


\section{Experimental Procedures}

We dissclved approximately $5 \mathrm{~g}$ of plutonfum oxide and measured the Isotopic abundances shown in Table 2 by mass spectrometry. For the first experiment, the ${ }^{237} U$ and ${ }^{241}$ Am were removed with chemical procedures using fon exchange columns to produce a solution simulating reprocessing plant conditions. The resulting solution had a concentration of 360 g/litre in $3 \mathrm{~N} \mathrm{HNO}_{3}$. Elght milliittres of this solution was accurately pipetted into the reservolr of the system, and the solution was circulated by a peristaltic pump. After the solution in the cells was counted, a known dilution of the solution was made using $3 \mathrm{~N} \mathrm{HNO}_{3}$ to permit a measurement at a new concentration. Four separate spectra were generally taken durfing each counting perfod, two counts for each cell configuration. That is, two duplicate spectra were taken of the thin cell and similarly, two transmission measurements were made. Many replicate spectra were taken during nighttime pertods, and these were used to study the prectsion of the analyses as well as drifts In the system.

In this way spectral measurements were taken at plutonium concentrations ranging from about $350 \mathrm{~g} / 11$ tre down to about $140 \mathrm{~g} /$ litre. The spectra were analyzed using computer programo that had been specifically written to reduce and interpret them.

The second experiment was conducted in essentlally the same way. However, In this case, the ${ }^{237} U$ was in secular equilibrium with its ${ }^{241}$ Pu parent, and ${ }^{241} \mathrm{Am}$ was added to the solution so that it simulated plutonfum that had aged about 1.5 y ars since chemlcal processing.

A ${ }^{238}$ Pu monttor was also added to the experimental setup because small drifts in detector efflciency were noted in the first experiment (see later discusstons). The ${ }^{238} \mathrm{Pu}$ was periodically counted to monttor changes in the counting efficiency.

Table 2. Isotopic content of plutonium used in experiments.

\begin{tabular}{cc}
\hline Isotope & $\begin{array}{c}\text { Abundance } \\
(\%)^{\mathrm{a}}\end{array}$ \\
\hline${ }^{238_{\mathrm{Pu}}}$ & 0.230 \\
$239_{\mathrm{Pu}}$ & 76.06 \\
$240 \mathrm{Pu}$ & 19.09 \\
${ }^{241_{\mathrm{Pu}}}$ & 2.98 \\
${ }^{242} \mathrm{Pu}$ & 1.64 \\
\hline aetermined by mass spectrometry.
\end{tabular}




\section{Discussion of Results}

EXPERIMENT USING RELENTLY REPROCESSED PLUTUNIUM

The starting volume in both experiments was $8 \mathrm{millilitres.} \mathrm{In}$ the first experisent, the initia] concentration was $360 \mathrm{~g} / \mathrm{litre}$, and eleven subsequent dilutions were made so that the final concentration was 130.1 g/litre. The measurements and dllutions were made over three days and two nights.

\section{Gamma Transmission Results}

Figure 11 shows the spectral region of the two transmission gamma rays. We observed a rather high and sloping background in Eront of the peak doublet, but we did not discover the cause for this until the experiment had been completed. At that time, we found that if the ${ }^{75} \mathrm{Se}-{ }^{57}$ Co source was backed away from the collimating hole of its container, then the background level dropped considerably. The obvious conclusion was that the 122-keV gamna rays of ${ }^{57}$ Co were being scattered through low angles from the surfaces of the collimator. The slightly degraded Compton radlations were now below the absorption edge of plutonium and were no longer severely atcenuated by the solution. Figure 12 shows this effect when $m l y$ a ${ }^{37} \mathrm{Co}$ source is used in two differing positions with respect to the coll1rating hole.

The fact that the above phenomena had occurred $1 \mathrm{n}$ this experiment, and indeed will always occur to some extent, complicated the exact shape of the background continum under the peaks. The two essential components of this continum are shown in Fig. 13. Qualitatively, the first component describes smoothed discontinuities in the background, centered at the respective peak positions with step: proportional to the intensities. This component is related to the gamma-ray Interaction process in the detector. The second is due to the differential transmission of the gamma-ray continuum. It results in an increasing background level with a smoothed discontinuity occurring at the $k$-shell absorption edge of plutonium.

To remove the effects of the background continuum, we wrote an algorithm so triat the resulting net counts for the peak doublet could be fitted by our standard peak fltting techniques. We achieved calibration by taking the peak height ratios (R) corrected for isotopic decay of the ${ }^{75} \mathrm{Se}$ and ${ }^{57} \mathrm{Co}$ sources and the concentrations (C) calculated from known dilution factors ("book" values). 


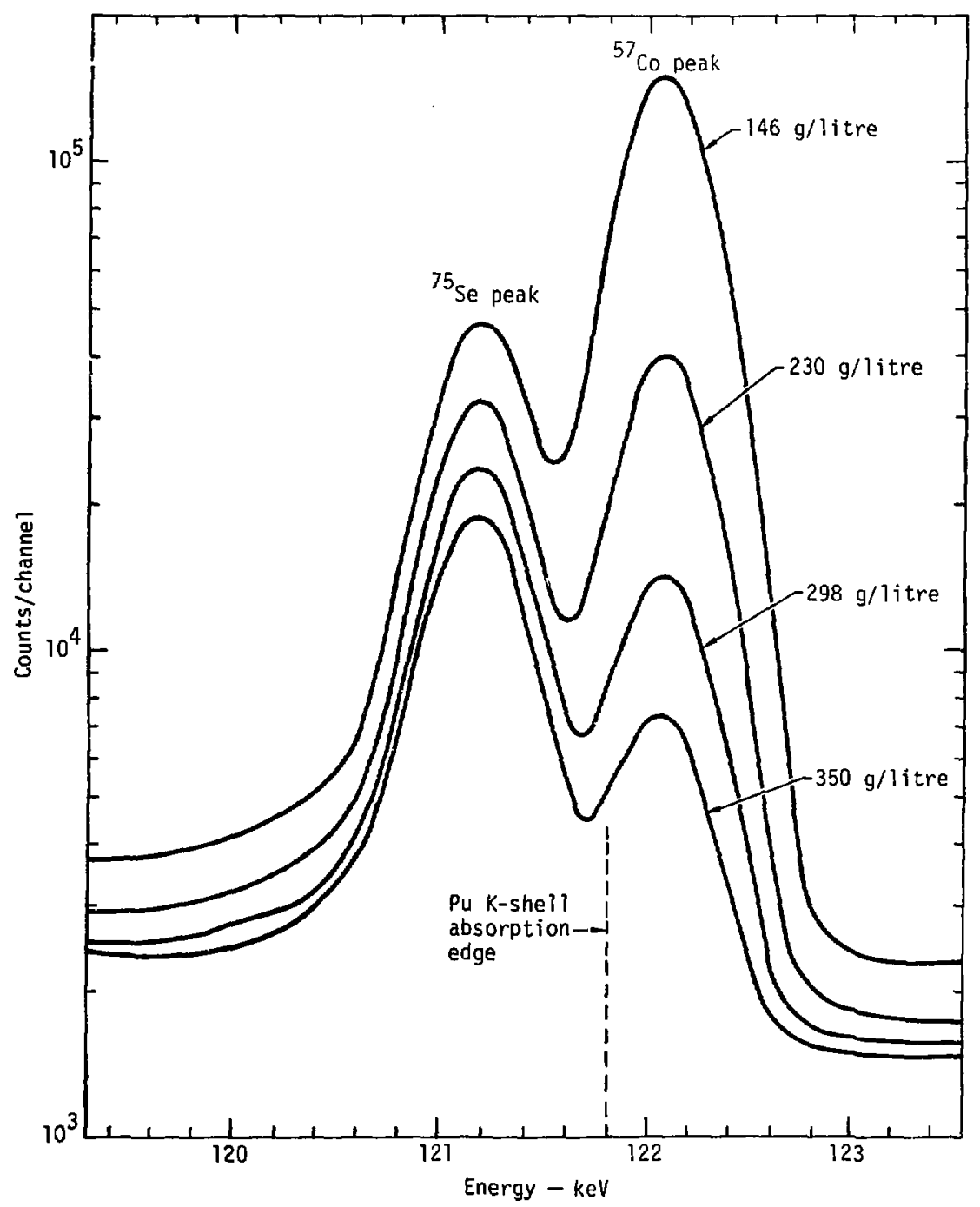

Fig. 11. Typical intensity distributions of transmitted peaks as a function of plutonium concentration. 


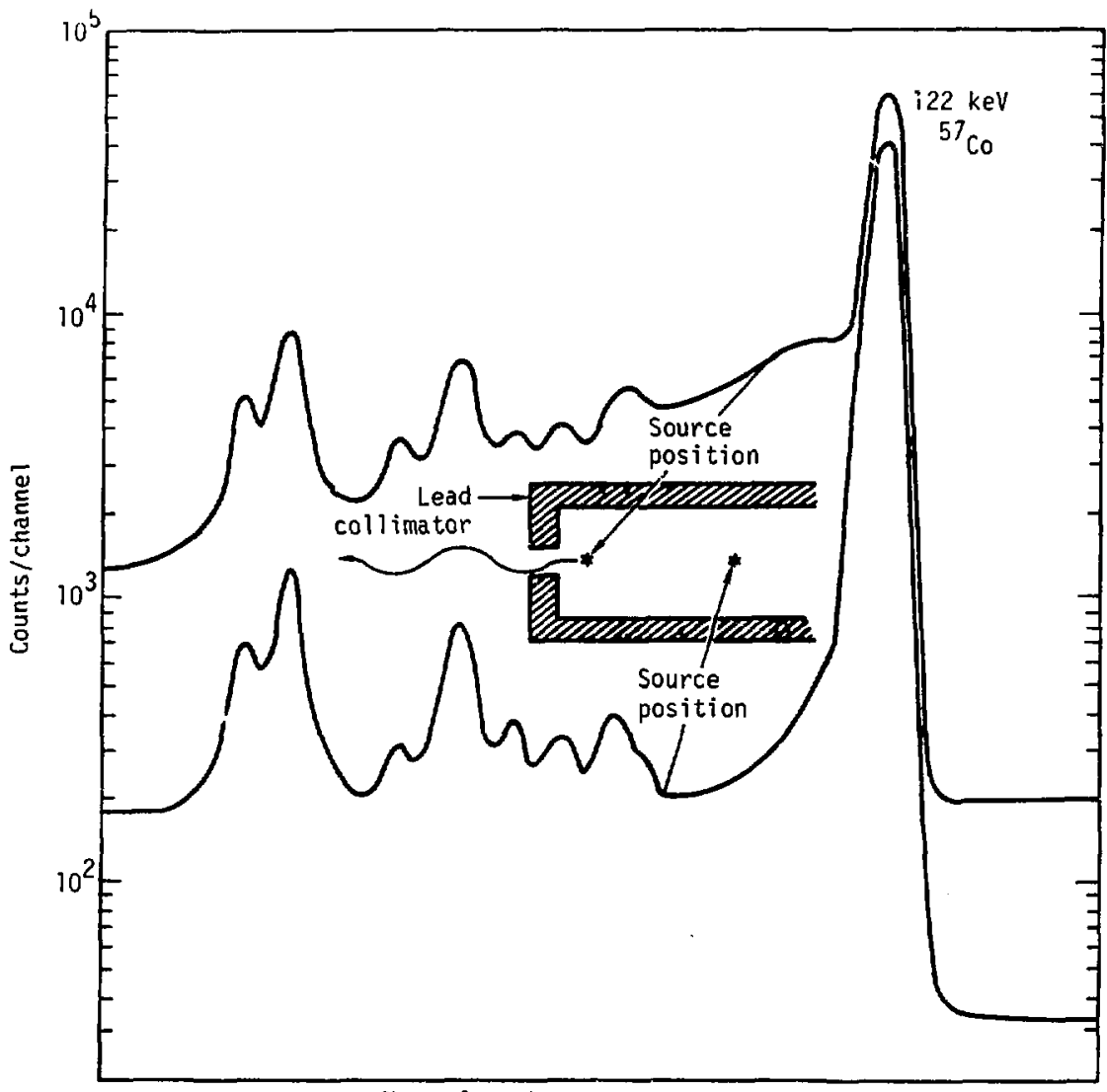

Channel number

Fig. 12. The upper spectrum shows the effect of scattering material around the transmission source. The resulting high continuum level can be reduced, as shown by the lower spectrum, by minfmizing the sources of low-angle scattering. 


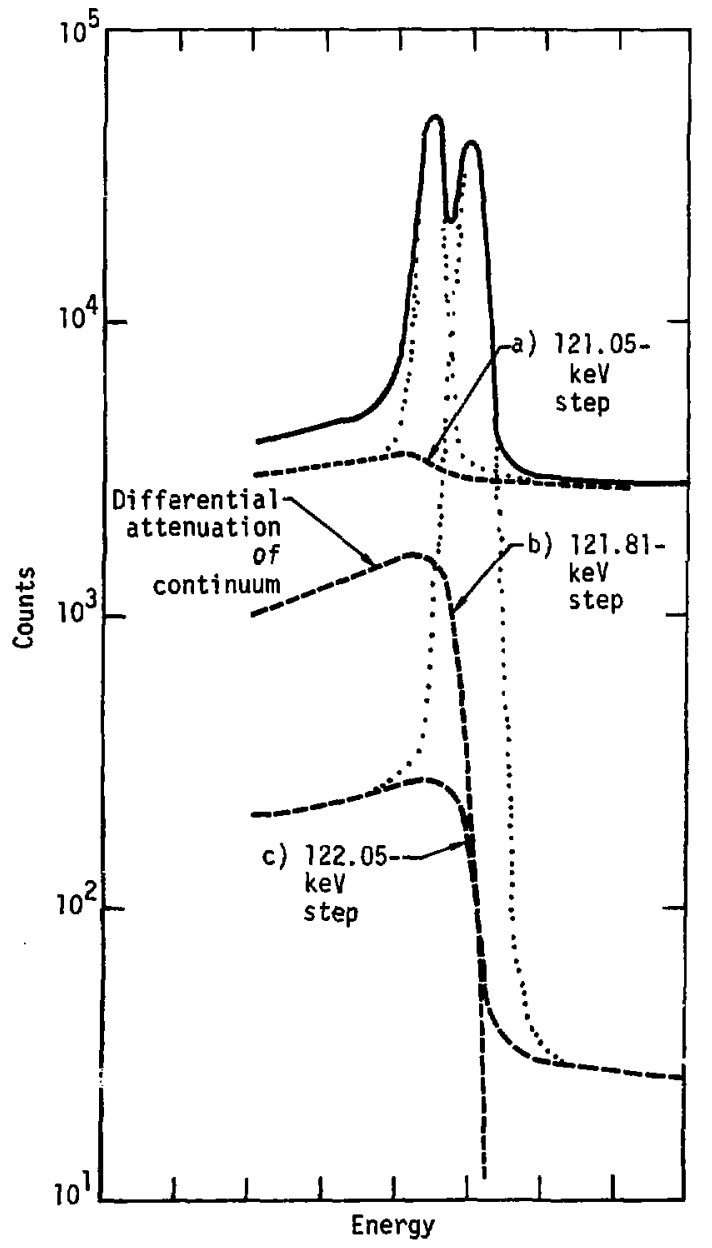

Fig. 13. The background continuum under the gamma-ray doublet is quite complex, consisting of steps at the peak positions (a) and (c) as well as a step at the absorption edge Itselt (b).

These we fitted by the method of least squares using the equation

$$
C 1=a+b \ln \left(k_{1}\right) .
$$

The resulting calibration constants, $a$ and $b$, were used to calcnlate the experimental concentrations from each peak height ratio measurement. These values are compared to the book values shown in Table 3 . With a few exceptions, the differences do not greatly exceed the statistical uncertainty 
lable 3. Results of differential transmission measurements on recently separated plutonium solutic.'s.

\begin{tabular}{|c|c|c|c|c|c|}
\hline \multirow{2}{*}{$\begin{array}{l}\text { Run } \\
\text { Yo. }\end{array}$} & \multirow{2}{*}{$\begin{array}{l}\text { Count tinue } \\
(\min )\end{array}$} & \multirow{2}{*}{$\begin{array}{l}\text { Peak height ratio } \\
(122 \mathrm{keV} / 121 \mathrm{keV})\end{array}$} & \multicolumn{3}{|c|}{ Pu concentration (g/litre) } \\
\hline & & & Book value & Measured & $\%$ difference \\
\hline $\begin{array}{l}\text { la } \\
1 \mathrm{~b}\end{array}$ & 20 & $\begin{array}{l}0.1097(1.3)^{\mathbf{a}} \\
0.1121\end{array}$ & 360.0 & $\begin{array}{l}355.1(0.4)^{\mathrm{a}} \\
357.1\end{array}$ & $\begin{array}{l}-0.26 \\
-0.80\end{array}$ \\
\hline $\begin{array}{l}2 \mathrm{a} \\
2 \mathrm{~b}\end{array}$ & 20 & $\begin{array}{l}0.1497(1.0) \\
0.1500\end{array}$ & 331.0 & $\begin{array}{l}331.4(0.35) \\
331.2\end{array}$ & $\begin{array}{l}0.12 \\
0.07\end{array}$ \\
\hline $\begin{array}{l}3 a \\
3 b\end{array}$ & 20 & $\begin{array}{l}0.1954(0.85) \\
0.2000\end{array}$ & 306.4 & $\begin{array}{l}307.8(0.3) \\
305.7\end{array}$ & $\begin{array}{r}0.45 \\
-0.23\end{array}$ \\
\hline $\begin{array}{l}4 a \\
4 b\end{array}$ & 20 & $\begin{array}{l}0.2490 \quad(0.75) \\
0.2507\end{array}$ & 285.1 & $\begin{array}{l}286.2(0.25) \\
285.6\end{array}$ & $\begin{array}{l}0.37 \\
0.16\end{array}$ \\
\hline $\begin{array}{l}5 a \\
5 b \\
5 c \\
5 d \\
5 e\end{array}$ & 60 & $\begin{array}{l}0.3091 \quad(0.4) \\
0.3078 \\
0.3075 \\
0.3073 \\
0.3072\end{array}$ & 266.7 & $\begin{array}{l}267.0(0.15) \\
267.4 \\
267.4 \\
267.5 \\
267.5\end{array}$ & $\begin{array}{l}0.12 \\
0.26 \\
0.29 \\
0.31 \\
0.32\end{array}$ \\
\hline $\begin{array}{l}6 a \\
6 b\end{array}$ & 20 & $\begin{array}{l}0.3703(0.5) \\
0.3710\end{array}$ & 250.4 & $\begin{array}{l}250.9(0.25) \\
250.8\end{array}$ & $\begin{array}{l}0.20 \\
0.13\end{array}$ \\
\hline $\begin{array}{l}7 \mathrm{a} \\
7 \mathrm{~b}\end{array}$ & 20 & $\begin{array}{l}0.4406(0.5) \\
0.4374\end{array}$ & 236.1 & $\begin{array}{l}235.5 \quad(0.25) \\
236.1\end{array}$ & $\begin{array}{r}-0.25 \\
0.03\end{array}$ \\
\hline $\begin{array}{l}8 a \\
8 b\end{array}$ & 20 & $\begin{array}{l}0.5739(0.4) \\
0.5777\end{array}$ & 211.8 & $\begin{array}{l}212.0(0.2) \\
211.4\end{array}$ & $\begin{array}{r}0.11 \\
-0.17\end{array}$ \\
\hline $\begin{array}{l}9 a \\
9 b\end{array}$ & 20 & $\begin{array}{l}0.7261 \quad(0.35) \\
0.7292\end{array}$ & 192.0 & $\begin{array}{l}191.1(0.2) \\
190.7\end{array}$ & $\begin{array}{l}-0.48 \\
-0.68\end{array}$ \\
\hline $\begin{array}{l}10 \mathrm{a} \\
10 \mathrm{~b}\end{array}$ & 20 & $\begin{array}{l}0.8602(0.35) \\
0.8622\end{array}$ & 175.6 & $\begin{array}{l}176.0(0.2) \\
175.8\end{array}$ & $\begin{array}{l}0.23 \\
0.11\end{array}$ \\
\hline 11 & 40 & $1.173(0.3)$ & 149.4 & $148.4(0.2)$ & -0.67 \\
\hline 12 & 40 & $1.471(0.3)$ & 130.0 & $128.2(0.2)$ & -1.37 \\
\hline
\end{tabular}

a Numbers in parentheses show approximate \% error for the indicated values in the group.

assigned to the measurement. However, explanations will be presented later. there does appear to be a small but definite nonlinearity to the fit as Fig. 14 shows. This phenomenon was also observed in some of the other experimental measurements; possible If an additional degree of freedom is permitted in the least-squares fitting, the relative standard deviation of the error can be reduced to approximately $0.3 \%$. 


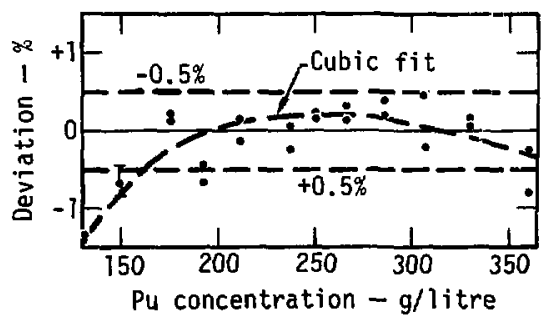

F1g. 14, Comparison of the total plutonium concentration in recently separated solutions as determined from transmission measurements with values calculated from known dilution factors. Small but definite nonlinearity is noted at the extremes of the range. $\sigma=0.44 \%$ linear fit, $0.30 \%$ cubic fit.

During the first nighttime period, we took repetitive cuunts of the transmission measurement. The results are included in Table 3 as entrles 5a through $5 \mathrm{e}$. These counts indicate that a precision approaching $0.1 \%$ can be achleved if sufficiently good counting statistics are acquired.

\section{Direct Counting Results}

Our experiment was designed not only to obtain data for isotopj.c ratio measurements but also to obta'.n quantitative assays for the measurable plutonium isotopes. Because ${ }^{242} \mathrm{Pu}$ is not directly measurable by gamma spectrometry, we planned an Indirect estimate of its abundance by subtracting the directly counted values of ${ }^{238} \mathrm{Pu},{ }^{239} \mathrm{Pu},{ }^{240} \mathrm{Pu}$, and ${ }^{241} \mathrm{Pu}$ from the total assay obtained by the differential transmission technique. This required considerable care in calibrating the detector, in charactertzing the operating performance of the system hardware and in writing analysis softwa:e that would properly interpret the resulting spectra.

One detall we did not consider in the first experiment was that the detector efficiency might drift slightly with time. We had experienced changes of several percent in the efficiency of small intrinsic and lithium-drifted deteciors in the past, but we had noted that these occurred when the decectors were new and that the effects were over sonsiderable time periods. To our knowledge, small changes in effictency of $1 \%$ or less over short periods of time (i.e., a few days) have not been studied.

During the second nighttine period, we took repeated counts of the thin, direct-counting cell. The change in the counting results is shown in Fig. 15. Subsequent experiments seem to confirm that the efficiency of small detectors can vary with time (see Fig. 16). We belleve this is due to small changes in the surface states of the detector that affect the efficiency with which events occurring near the surface are collected. 4,10

Having noted that the detector efficiency did apparently drift during 


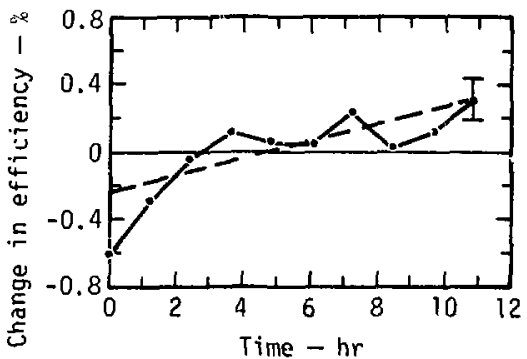

FIg. 15. Repetitive counts of the direct counting cell indicate an efficiency drift of about $0.5 \%$ during an overnight period of time.

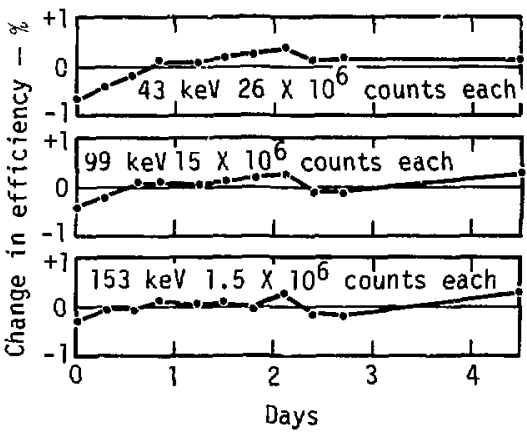

Figj 16. Repetittve counts of a Pu monitor over several days conf Irm that efficiency drifts of about $1 \%$ can occur.

the course of the experiment, we renormalized the original data so that the last count of one day agreed witin the beginning count of the succeeding day taken at the same concentration.

An approximate calibration was made for the varinus detector efficiency parameters, and the resulting analyses were fitted by least squares to the true concentration value. A linear fit made in this way gave agreement, as shown by Table 4 and Fig. 17. Two results to be noted in the fit are that there is a definite nonlinear component in the measurement and that the intercepls are not at the ortgin. Several possible causes can be postwiated for these l'esults and additional experiments will be required to fully understand the proilem. Even so, the results are encouraging and, as Table 4 and Fig. 17 show, the fit improves significantly with one additional degree of freedom.

Results of Isotopj.c Ratio Measurements

The experiment also allowed us to study the precision with which isotopic ratio measurements can he made as a function of plutonium concentration. The measurements are summarized in Table 5. The isotopic abundances show very little change with concentration. The standard deviatson calculated from the reproductbility, however, appears to be somewhat worse than that permitted by statistical error alone, inplying that esther the procedures used for determining the uncertainties in the measured values are not exact or that nonstatistical sources of error are preseut.

The ${ }^{242} \mathrm{Pu}$ isutopic content reported in Table 5 was not determined by direct counting but was calculated 
Table 4. Results of direct gamma counting of recently separated plutorium solutions.

\begin{tabular}{|c|c|c|c|c|c|c|}
\hline \multirow[b]{2}{*}{$\begin{array}{l}\text { Run } \\
\text { No. }\end{array}$} & \multirow[b]{2}{*}{$\begin{array}{l}\text { Count } \\
\text { time (min) }\end{array}$} & \multicolumn{5}{|c|}{ Pu concentration excluding ${ }^{242} \mathrm{Pu}$ (g/litre) } \\
\hline & & $\begin{array}{l}\text { Book } \\
\text { value }\end{array}$ & Measured $^{a}$ & $\%$ difference & Measured $^{a}$ & $\%$ difference \\
\hline $\begin{array}{l}1 \mathrm{a} \\
1 \mathrm{~b}\end{array}$ & 10 & 354.1 & $\begin{array}{l}353.0 \\
353.9\end{array}$ & $\begin{array}{l}-0.32 \\
-0.05\end{array}$ & $\begin{array}{l}354.1 \\
355.1\end{array}$ & $\begin{array}{l}0.00 \\
0.28\end{array}$ \\
\hline $\begin{array}{l}2 \mathrm{a} \\
2 \mathrm{~b}\end{array}$ & 10 & 325.6 & $\begin{array}{l}324.1 \\
324.9\end{array}$ & $\begin{array}{l}-0.47 \\
-0.20\end{array}$ & $\begin{array}{l}324.4 \\
325.3\end{array}$ & $\begin{array}{l}-0.37 \\
-0.09\end{array}$ \\
\hline $\begin{array}{l}3 \mathrm{a} \\
3 \mathrm{~b}\end{array}$ & 10 & 301.3 & $\begin{array}{l}300.2 \\
301.6\end{array}$ & $\begin{array}{r}-0.39 \\
0.09\end{array}$ & $\begin{array}{l}300.0 \\
301.5\end{array}$ & $\begin{array}{r}-0.44 \\
0.05\end{array}$ \\
\hline $\begin{array}{l}4 a \\
4 b\end{array}$ & 10 & 280.5 & $\begin{array}{l}281.8 \\
280.7\end{array}$ & $\begin{array}{l}0.48 \\
0.09\end{array}$ & $\begin{array}{l}281.4 \\
280.3\end{array}$ & $\begin{array}{r}0.34 \\
-0.07\end{array}$ \\
\hline 5 & 10 & 262.3 & 263.2 & 0.34 & 262.6 & 0.12 \\
\hline $\begin{array}{l}6 \mathrm{a} \\
6 \mathrm{~b}\end{array}$ & 12 & 246.3 & $\begin{array}{l}247.3 \\
247.5\end{array}$ & $\begin{array}{l}0.40 \\
0.48\end{array}$ & $\begin{array}{l}246.7 \\
246.9\end{array}$ & $\begin{array}{l}0.13 \\
0.22\end{array}$ \\
\hline $\begin{array}{l}7 \mathrm{a} \\
7 \mathrm{~b}\end{array}$ & 12 & 232.2 & $\begin{array}{l}233.6 \\
233.1\end{array}$ & $\begin{array}{l}0.58 \\
0.41\end{array}$ & $\begin{array}{l}232.9 \\
232.5\end{array}$ & $\begin{array}{l}0.30 \\
0.13\end{array}$ \\
\hline $\begin{array}{l}8 \mathrm{a} \\
8 \mathrm{~b}\end{array}$ & 15 & 208.3 & $\begin{array}{l}208.6 \\
208.8\end{array}$ & $\begin{array}{l}0.16 \\
0.25\end{array}$ & $\begin{array}{l}208.1 \\
208.3\end{array}$ & $\begin{array}{r}-0.09 \\
0.00\end{array}$ \\
\hline $\begin{array}{l}9 a \\
9 b\end{array}$ & 15 & 188.9 & $\begin{array}{l}188.18 \\
188.6\end{array}$ & $\begin{array}{l}-0.05 \\
-0.13\end{array}$ & $\begin{array}{l}188.5 \\
1.88 .3\end{array}$ & $\begin{array}{l}-0.20 \\
-0.28\end{array}$ \\
\hline 10 & 60 & 172.7 & 172.4 & -0.19 & 172.4 & -0.19 \\
\hline 11 & 30 & 147.0 & 145.8 & -0.80 & 146.4 & -0.39 \\
\hline $\begin{array}{l}12 a \\
12 b\end{array}$ & $\begin{array}{l}30 \\
15\end{array}$ & $\mathbf{1} 28.0$ & $\begin{array}{l}127.0 \\
1.27 .4\end{array}$ & $\begin{array}{l}-0.77 \\
-0.46\end{array}$ & $\begin{array}{l}128.1 \\
128.5\end{array}$ & $\begin{array}{l}0.14 \\
0.44\end{array}$ \\
\hline \multicolumn{6}{|c|}{ Relative standard deviation $\sigma=0.41$} & $\sigma=0.26$ \\
\hline
\end{tabular}

ahe first column of measured values shows a linear fit whereas the second column shows a cubic fit. The error in the measured values due to caunting statistics is about $0.1 \%$.

from the difference in value between the total plutonium concentration measured by the differential attenuation technique and the isotopic sum value of measurable plutonium 1sotopes by direct counring.
EXPERIMENT USING AGED PLUTONIUM

The experiment using aged plutonium solution was conducted in much the same way as the preceding experiment, However, in this experiment, we counted a ${ }^{238} \mathrm{Pu}$ sample periodically 
Table 5. Isotopic ratio measurements of recentiy separated plutontum solutions.

\begin{tabular}{|c|c|c|c|c|c|c|}
\hline Run No. & Total concentration & ${ }^{238} \mathrm{Pu}$ & ${ }^{239} \mathrm{Pu}$ & ${ }^{240} \mathrm{Pu}$ & ${ }^{241} \mathrm{Pu}$ & ${ }^{242} \mathrm{Pu}^{a}$ \\
\hline $\begin{array}{l}1 \mathrm{a} \\
1 \mathrm{~b}\end{array}$ & 360.0 & $\begin{array}{l}0.2229 \\
0.2305\end{array}$ & $\begin{array}{l}76.070 \\
76.064\end{array}$ & $\begin{array}{l}19.08 \\
19.11\end{array}$ & $\begin{array}{l}3.022 \\
2.992\end{array}$ & $\begin{array}{l}1.39 \\
0.56\end{array}$ \\
\hline $\begin{array}{l}2 a \\
2 b\end{array}$ & 331.0 & $\begin{array}{l}0.2313 \\
0.2306\end{array}$ & $\begin{array}{l}75.919 \\
76.028\end{array}$ & $\begin{array}{l}19.22 \\
19.13\end{array}$ & $\begin{array}{l}3.032 \\
3.009\end{array}$ & $\begin{array}{l}2.11 \\
1.78\end{array}$ \\
\hline $\begin{array}{l}3 \mathrm{a} \\
3 \mathrm{~b}\end{array}$ & 306.4 & $\begin{array}{l}0.2317 \\
0.2306\end{array}$ & $\begin{array}{l}75.947 \\
76.003\end{array}$ & $\begin{array}{l}19.20 \\
19.16\end{array}$ & $\begin{array}{l}3.017 \\
3.005\end{array}$ & $\begin{array}{l}2.54 \\
1.37\end{array}$ \\
\hline $\begin{array}{l}4 a \\
4 b\end{array}$ & 285.1 & $\begin{array}{l}0.2317 \\
0.2327\end{array}$ & $\begin{array}{l}76.101 \\
75.992\end{array}$ & $\begin{array}{l}19.09 \\
19.13\end{array}$ & $\begin{array}{l}2.997 \\
3.042\end{array}$ & $\begin{array}{l}1.68 \\
1.86\end{array}$ \\
\hline $\begin{array}{l}5 a \\
5 b\end{array}$ & 266.7 & $\begin{array}{l}0.2305 \\
0.2315\end{array}$ & $\begin{array}{l}75.987 \\
76.037\end{array}$ & $\begin{array}{l}19.16 \\
19.10\end{array}$ & $\begin{array}{l}3.022 \\
3.034\end{array}$ & 1.83 \\
\hline $\begin{array}{l}6 a \\
6 b\end{array}$ & 250.4 & $\begin{array}{l}0.2313 \\
0.2309\end{array}$ & $\begin{array}{l}75.987 \\
76.081\end{array}$ & $\begin{array}{l}19.17 \\
19.09\end{array}$ & $\begin{array}{l}3.008 \\
2.997\end{array}$ & $\begin{array}{l}1.68 \\
1.56\end{array}$ \\
\hline $\begin{array}{l}7 a \\
7 b\end{array}$ & 236.1 & $\begin{array}{l}0.2310 \\
0.2309\end{array}$ & $\begin{array}{l}76.058 \\
76.112\end{array}$ & $\begin{array}{l}19.10 \\
19.04\end{array}$ & $\begin{array}{l}3.009 \\
3.017\end{array}$ & $\begin{array}{l}1.40 \\
1.52\end{array}$ \\
\hline $\begin{array}{l}8 \mathbf{a} \\
8 \mathbf{b}\end{array}$ & 211.8 & $\begin{array}{l}0.2316 \\
0.2302\end{array}$ & $\begin{array}{l}76.009 \\
76.052\end{array}$ & $\begin{array}{l}19.16 \\
19.09\end{array}$ & $\begin{array}{l}2.996 \\
3.030\end{array}$ & $\begin{array}{l}1.84 \\
1.46\end{array}$ \\
\hline $\begin{array}{l}9 a \\
9 b\end{array}$ & 192.0 & $\begin{array}{l}0.2321 \\
0.2301\end{array}$ & $\begin{array}{l}76.003 \\
76.054\end{array}$ & $\begin{array}{l}19.14 \\
19.09\end{array}$ & $\begin{array}{l}3.026 \\
3.023\end{array}$ & $\begin{array}{l}1.35 \\
1.25\end{array}$ \\
\hline $\begin{array}{l}10 \mathrm{a} \\
10 \mathrm{~b} \\
10 \mathrm{c} \\
10 \mathrm{~d} \\
10 \mathrm{e} \\
10 \mathrm{f} \\
10 \mathrm{~g} \\
10 \mathrm{~h} \\
101 \\
10 \mathrm{j}\end{array}$ & 175.6 & $\begin{array}{l}0.2316 \\
0.2316 \\
0.2322 \\
0.2319 \\
0.2330 \\
0.2323 \\
0.2329 \\
0.2325 \\
0.2335 \\
0.2336\end{array}$ & $\begin{array}{l}76.119 \\
76.088 \\
76.088 \\
76.112 \\
76.088 \\
76.114 \\
76.131 \\
76.051 \\
76.093 \\
76.023\end{array}$ & $\begin{array}{l}19.04 \\
19.05 \\
19.06 \\
19.05 \\
19.06 \\
19.04 \\
19.03 \\
19.09 \\
19.06 \\
19.10\end{array}$ & $\begin{array}{l}3.009 \\
3.011 \\
3.009 \\
2.998 \\
3.012 \\
3.005 \\
2.992 \\
3.008 \\
3.004 \\
3.016\end{array}$ & $\begin{array}{c}2.00 \\
- \\
- \\
- \\
- \\
- \\
- \\
- \\
- \\
-\end{array}$ \\
\hline 11 & 149.4 & 0.2330 & 76.004 & 19.15 & 3.018 & 1.34 \\
\hline \multirow[t]{3}{*}{$\begin{array}{l}12 \mathrm{a} \\
12 \mathrm{~b}\end{array}$} & 130.0 & $\begin{array}{l}0.2327 \\
0.2291\end{array}$ & $\begin{array}{l}76.002 \\
76.001\end{array}$ & $\begin{array}{l}19.16 \\
19.16\end{array}$ & $\begin{array}{l}3.007 \\
3.010\end{array}$ & $\begin{array}{c}-0.23 \\
-\end{array}$ \\
\hline & Average & 0.2317 & 76.046 & 19.10 & 3.011 & $1+51$ \\
\hline & $\begin{array}{l}\text { ative } \\
\text { adard deviation }\end{array}$ & $\pm 0.46 \%$ & $\pm 0.07 \%$ & $\pm 0.26 \%$ & $\pm 0.45 \%$ & $\pm 38 \%$ \\
\hline
\end{tabular}

$a_{\text {The tsotopte values for }}{ }^{242} \mathrm{Pu}$ were not obtained by direct measurements but by subtracting the direct counting measurements of Table 4 from the differential transmission measurements of Table 3. 


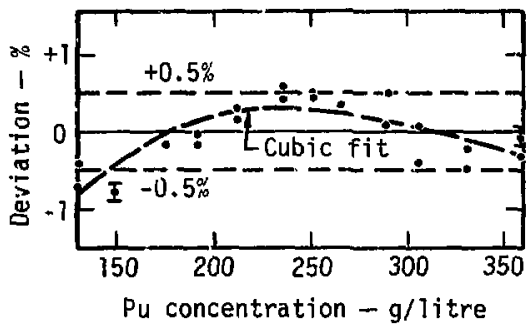

F1g. 17. Comparison of plutonium isotopic sum (exclustve of ${ }^{242} \mathrm{Pu}$ ) from direct counting of recently separated solution with values calculated from known dilution factors. A nonlinearity similar to that shown in Fig. 14 appears to be present. $\sigma=0.41 \%$ 11near fit, $0.26 \%$ cublc fic. to monitor the stability of the countfing efficiency. The results of these counts are shown in FLg. 18. The data are somewhat ambiguous but, as in the first experiment, small changes in counting efficlency are apparent. The starting concentration for this experiment was $350.4 \mathrm{~g} /$ litre. Eleven dilutions were made resulting in a final concentration of $146.0 \mathrm{~g} / 11 \mathrm{tre}$. Gamma Transmission Results

In this experiment, the ${ }^{75} \mathrm{Se}-{ }^{57} \mathrm{Co}$ source was backed away from the collimating hole of its shield. This

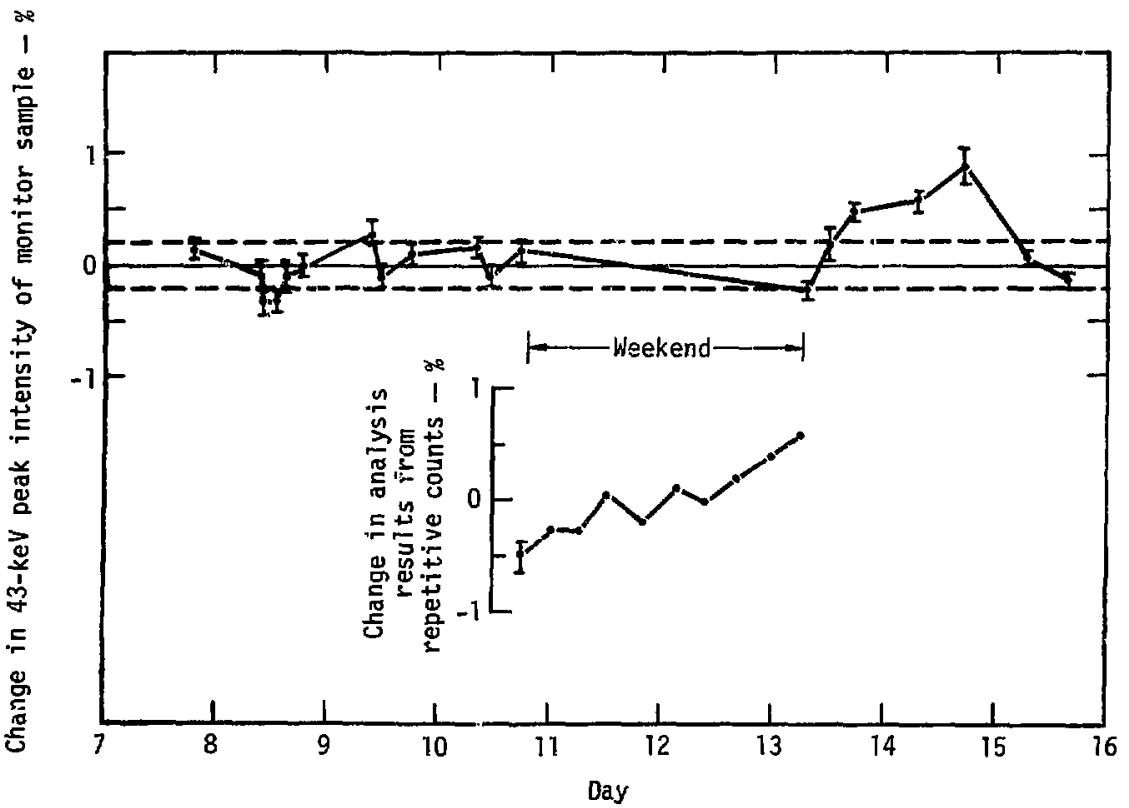

F1g. 18. Results of the ${ }^{238} \mathrm{Pu}$ : monitor during the second experiment. 
reduced but did not completely eliminate the lowmanle scattering of the $122-k e{ }^{2}$ radiation of ${ }^{57} \mathrm{Co}$. The analysis and interpretation of the two transmission gamma rays was similar to that described for the first experiment. The peak hefglit ratios and true values of the concentration were again fitted by least squares to E.q. (5), resulting in a fit as shown in Table 6 and Pig. 19. The relative standard deviation of the error of 0.35 is similar to that obtained in the first experiment and appears to

Table 6. Results of differential transmission measurements on aged plutontum solutions.

\begin{tabular}{|c|c|c|c|c|c|}
\hline \multirow{2}{*}{$\begin{array}{l}\text { Run } \\
\text { No. }\end{array}$} & \multirow{2}{*}{$\begin{array}{l}\text { Count } \\
\text { time (min) }\end{array}$} & \multirow{2}{*}{$\begin{array}{l}\text { Peak height ratio } \\
(122 \mathrm{keV} / 12 . \mathrm{kev})\end{array}$} & \multicolumn{3}{|c|}{ Pu concentration (g/11tre) } \\
\hline & & & Book value & Measured & difference \\
\hline $\begin{array}{l}1 \mathrm{a} \\
1 \mathrm{~b}\end{array}$ & 20 & $\begin{array}{l}0.3472(1.0)^{d} \\
0.3513(0.8)\end{array}$ & 350.4 & $\begin{array}{l}349.0(0.3)^{a} \\
347.9(0.2)\end{array}$ & $\begin{array}{l}-0.40 \\
-0.71\end{array}$ \\
\hline $\begin{array}{l}2 a \\
2 b\end{array}$ & 30 & $\begin{array}{l}0.4656 \quad(0.6) \\
0.4628\end{array}$ & 322.2 & $\begin{array}{l}322.3(0.2) \\
322.8\end{array}$ & $\begin{array}{l}0.02 \\
0.19\end{array}$ \\
\hline $\begin{array}{l}3 \mathrm{a} \\
3 \mathrm{~b}\end{array}$ & $\begin{array}{l}30 \\
15\end{array}$ & $\begin{array}{ll}0.6040 & (0.6) \\
0.6031 & (0.7)\end{array}$ & 298.2 & $\begin{array}{l}293.6(0.2) \\
298.7\end{array}$ & $\begin{array}{l}0.12 \\
0.17\end{array}$ \\
\hline 4 & 60 & $0.7519(0.3)$ & 277.5 & $278.6(0.1)$ & 0.40 \\
\hline $\begin{array}{l}5 \mathrm{a} \\
5 \mathrm{~b}\end{array}$ & $\begin{array}{l}45 \\
51\end{array}$ & $\begin{array}{l}0.9095(0.3) \\
0.9142\end{array}$ & 259.5 & $\begin{array}{l}261.3(0.2) \\
260.8\end{array}$ & $\begin{array}{l}0.68 \\
0.50\end{array}$ \\
\hline $\begin{array}{l}6 \mathrm{a} \\
6 \mathrm{~b}\end{array}$ & $\begin{array}{l}26 \\
28\end{array}$ & $\begin{array}{l}1.107(0.4) \\
1.096\end{array}$ & 243.7 & $\begin{array}{l}243.4(0.1) \\
244.3\end{array}$ & $\begin{array}{r}-0.12 \\
0.23\end{array}$ \\
\hline $\begin{array}{l}7 a \\
7 b\end{array}$ & $\begin{array}{l}30 \\
35\end{array}$ & $\begin{array}{l}1.288(0.4) \\
1.285\end{array}$ & 229.8 & $\begin{array}{l}229.6(0.1) \\
229.8\end{array}$ & $\begin{array}{l}-0.10 \\
-0.01\end{array}$ \\
\hline $\begin{array}{l}8 a \\
8 b\end{array}$ & $\begin{array}{l}32 \\
21\end{array}$ & $\begin{array}{l}1.663(0.3) \\
1.664(0.4)\end{array}$ & 206.1 & $\begin{array}{l}206.3(0.1) \\
206.2(0.2)\end{array}$ & $\begin{array}{l}0.09 \\
0.07\end{array}$ \\
\hline $\begin{array}{l}9 a \\
9 b\end{array}$ & $\begin{array}{l}72 \\
97\end{array}$ & $\begin{array}{l}2.052(0.2) \\
2.052\end{array}$ & 186.9 & $\begin{array}{l}187.2(0.1) \\
187.2\end{array}$ & $\begin{array}{l}0.14 \\
0.14\end{array}$ \\
\hline $\begin{array}{l}10 a \\
10 b \\
10 c\end{array}$ & $\begin{array}{l}200 \\
200 \\
182\end{array}$ & $\begin{array}{l}2.450(0.1) \\
2.448 \\
2.450\end{array}$ & 170.9 & $\begin{array}{l}171.0(0.05) \\
171.1 \\
171.0\end{array}$ & $\begin{array}{l}0.07 \\
0.11 \\
0.07\end{array}$ \\
\hline $\begin{array}{l}11 a \\
11 b\end{array}$ & $\begin{array}{l}15 \\
20\end{array}$ & $\begin{array}{l}2.869(0.3) \\
2.874\end{array}$ & 157.5 & $\begin{array}{l}156.6(0.2) \\
156.5\end{array}$ & $\begin{array}{l}-0.55 \\
-0.65\end{array}$ \\
\hline \multirow[t]{2}{*}{$\begin{array}{l}12 a \\
12 b\end{array}$} & 60 & $\begin{array}{l}3.246(0.2) \\
3.245\end{array}$ & 146.0 & $\begin{array}{l}145.4(0.1) \\
145.4\end{array}$ & $\begin{array}{l}-0.42 \\
-0.40\end{array}$ \\
\hline & \multicolumn{4}{|c|}{ Relative standard deviation $(\sigma)=$} & $=0.35$ \\
\hline
\end{tabular}

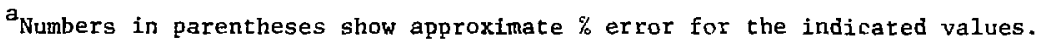




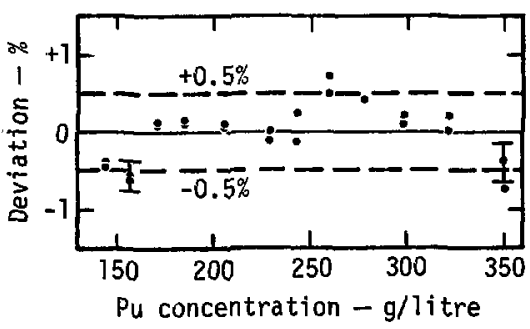

Fig. 19. Comparison of total plutonium concentration from transmisston measurements of aged solution with values calculated from known dilution factors. $\sigma=0.35 \%$.

be only slightly greater than the statistical uncertainties associated with the individual measurement. The most pronounced deviations appear to be at the extremes of the concentration range, indicating that the nonIinearity may be due to the imbalance In the relative intensities of the two peaks.

\section{Direct Counting Results}

Direct measurement of plutonium isotopes in aged material is more difficult than it is for recently processed solution. ThIs is because the presence of ${ }^{237} \mathrm{U}$ and ${ }^{241} \mathrm{Am}$ obscures the low-energy part of the spectrum and complicates other parts. To compensate, longer counting periods are required to obtain the desired accuracy, and a more sophisticated computer program is necessary to interpret the spectra.
After we determined the detector system parameters and efficiency coefficients required by the analysis program, the spectra were interpreted by the computer and the results were compared with known concentration values. As in the first experiment, we had to renormalize the data at certain points in the experiment. In this experiment, the ${ }^{238} \mathrm{Pu}$ monitor Indicated the direction and magnitude of the drift of counting efficiency. The only renormalization that appeared justifled was after a weekend, during which repetitive counts were taken. A linear fit of the experimentally measured values and true values is shown in Table 7 and Fig. 20. The relative standard deviation approached $0.25 \%$ in this experiment with very little indication of nonlinearity. The first coefficient of the linear fit was not, however, equal to zero, Indicating that the line did not quite pass through the origin.

\section{Results of Isotopic Ratio Measurements}

The analysis program for this case computes assay results for ${ }^{241} \mathrm{Am}$ as well as for the isotopes of plutonium. The individual results are given in Table 8 from which relative standard deviations can be calculated. As with the first experiment, there is very little bias in isotopic results with change in plutonium concentration. 
Table 7. Results of direct gamma counting of aged plutonfum solutions.

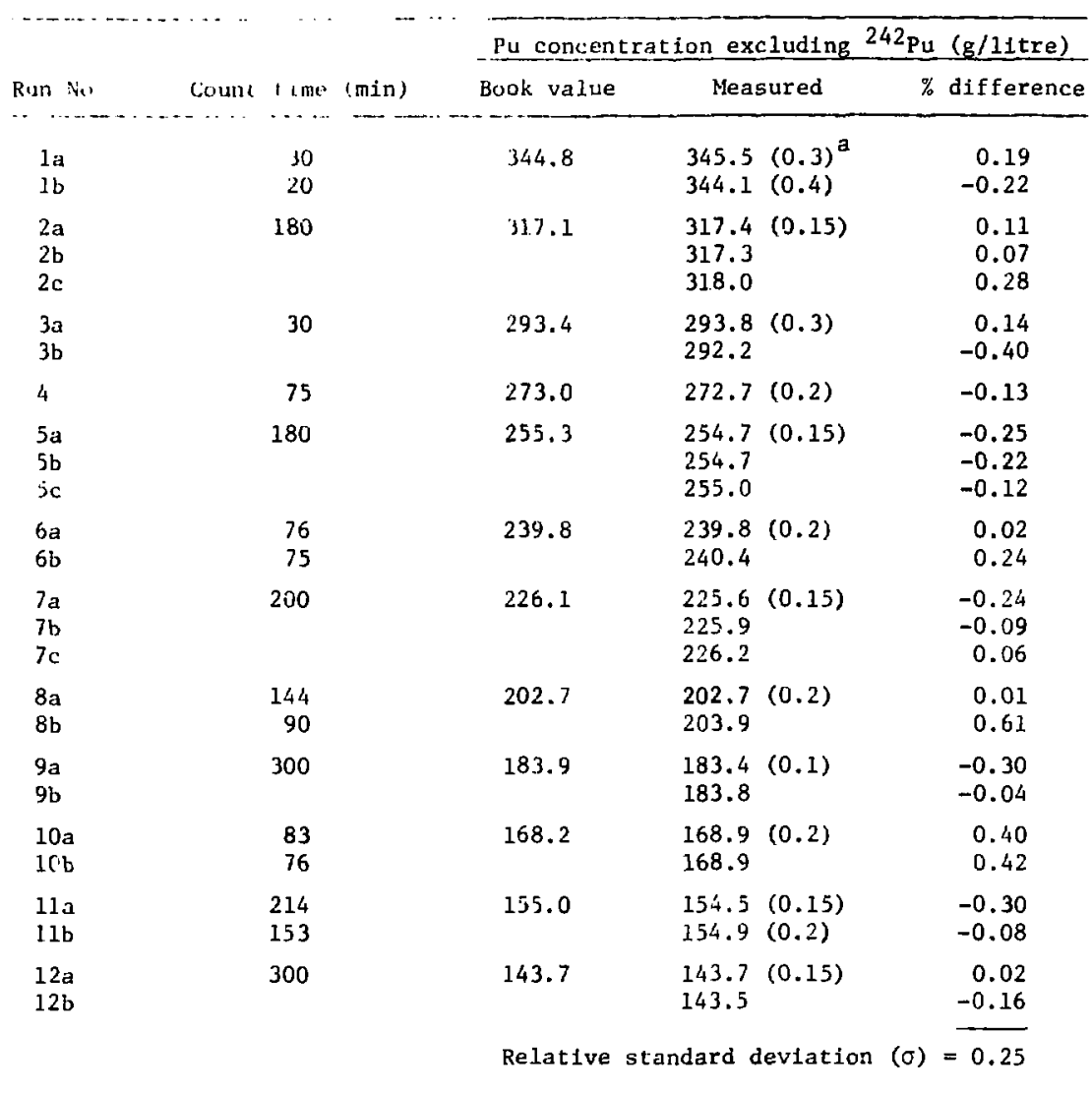

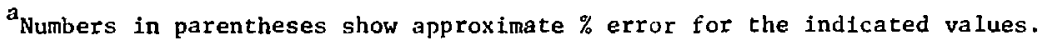

Fig. 20. Comparison of plutonium isotopic sum (excluding $242 \mathrm{Pu}$ ) from direct counting of aged solution with values calculated from known dilution factors. $\sigma=0.25 \%$.

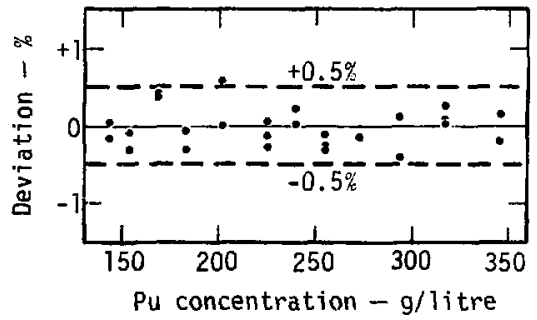


Table 8. Isotopic ratio measurements of aged plutonium solutions.

\begin{tabular}{|c|c|c|c|c|c|c|c|}
\hline $\begin{array}{l}\text { Run } \\
\text { Ne. }\end{array}$ & $\begin{array}{c}\text { Toral Pu } \\
\text { concentration }\end{array}$ & ${ }^{238} \mathrm{Pu}$ & ${ }^{239} \mathrm{pu}_{\mathrm{u}}$ & ${ }^{240} \mathrm{Pu}$ & ${ }^{241} \mathrm{Pu}$ & ${ }^{241} \mathrm{Am}$ & ${ }^{242} \mathrm{Pu}^{a}$ \\
\hline $\begin{array}{l}1 \mathrm{a} \\
1 \mathrm{~b}\end{array}$ & 350.4 & - & $\begin{array}{l}76.08 \\
76.00\end{array}$ & $\begin{array}{l}19.12 \\
19.19\end{array}$ & $\begin{array}{l}2.970 \\
2.986\end{array}$ & $\begin{array}{l}0.1759 \\
0.1769\end{array}$ & $\begin{array}{l}1.00 \\
1.09\end{array}$ \\
\hline $\begin{array}{l}2 a \\
2 b \\
2 c\end{array}$ & 322.2 & $\begin{array}{l}- \\
-\end{array}$ & $\begin{array}{l}76.12 \\
76.17 \\
76.24\end{array}$ & $\begin{array}{l}19.11 \\
19.06 \\
19.00\end{array}$ & $\begin{array}{l}2.970 \\
2.973 \\
2.970\end{array}$ & $\begin{array}{l}0.1758 \\
0.1764 \\
0.1763\end{array}$ & $\begin{array}{c}1.52 \\
1.71 \\
-\end{array}$ \\
\hline $\begin{array}{l}3 \mathrm{a} \\
3 \mathrm{~b}\end{array}$ & 298.2 & $\begin{array}{l}0.2320 \\
0.2322\end{array}$ & $\begin{array}{l}76.06 \\
76.05\end{array}$ & $\begin{array}{l}19.18 \\
19.18\end{array}$ & $\begin{array}{l}2.967 \\
2.986\end{array}$ & $\begin{array}{l}0.1753 \\
0.1766\end{array}$ & $\begin{array}{l}1.61 \\
2.18\end{array}$ \\
\hline 4 & 277.5 & 0.2319 & 76.02 & 19.21 & 2.980 & 0.1760 & 1.73 \\
\hline $\begin{array}{l}5 a \\
5 b \\
5 c\end{array}$ & 259.5 & $\begin{array}{l}0.2312 \\
0.2296 \\
0.2313\end{array}$ & $\begin{array}{l}76.13 \\
76.13 \\
76.07\end{array}$ & $\begin{array}{l}19.10 \\
19.10 \\
19.16\end{array}$ & $\begin{array}{l}2.982 \\
2.982 \\
2.984\end{array}$ & $\begin{array}{l}0.1760 \\
0.1765 \\
0.1765\end{array}$ & $\begin{array}{c}2.54 \\
2.35 \\
-\end{array}$ \\
\hline $\begin{array}{l}6 a \\
6 b\end{array}$ & 243.7 & $\begin{array}{l}0.2311 \\
0.2303\end{array}$ & $\begin{array}{l}76.14 \\
76.08\end{array}$ & $\begin{array}{l}19.10 \\
15.16\end{array}$ & $\begin{array}{l}2.980 \\
2.977\end{array}$ & $\begin{array}{l}0.1757 \\
0.1754\end{array}$ & $\begin{array}{l}1.48 \\
1.60\end{array}$ \\
\hline $\begin{array}{l}7 a \\
7 b \\
7 c\end{array}$ & 299.8 & $\begin{array}{l}0.2304 \\
0.2307 \\
0.2304\end{array}$ & $\begin{array}{l}76.11 \\
76.12 \\
76.11\end{array}$ & $\begin{array}{l}19.12 \\
19.11 \\
19.12\end{array}$ & $\begin{array}{l}2.989 \\
2.985 \\
2.982\end{array}$ & $\begin{array}{l}0.1761 \\
0.1761 \\
0.1760\end{array}$ & $\begin{array}{c}1.74 \\
1.70 \\
-\end{array}$ \\
\hline $\begin{array}{l}8 a \\
8 b\end{array}$ & 206.1 & $\begin{array}{l}0.2298 \\
0.2286\end{array}$ & $\begin{array}{l}76.18 \\
76.11\end{array}$ & $\begin{array}{l}19.06 \\
19.14\end{array}$ & $\begin{array}{l}2.975 \\
2.965\end{array}$ & $\begin{array}{l}0.1753 \\
0.1748\end{array}$ & $\begin{array}{l}1.75 \\
1.11\end{array}$ \\
\hline $\begin{array}{l}9 a \\
9 b \\
9 c \\
9 d \\
9 e \\
9 f \\
9 g \\
9 b \\
9 i \\
9 j\end{array}$ & 186.9 & $\begin{array}{l}0.2307 \\
0.2296 \\
0.2292 \\
0.2296 \\
0.2295 \\
0.2294 \\
0.2305 \\
0.2288 \\
0.2304 \\
0.2295\end{array}$ & $\begin{array}{l}76.08 \\
76.16 \\
76.12 \\
76.06 \\
76.16 \\
76.13 \\
76.13 \\
76.20 \\
76.15 \\
76.12\end{array}$ & $\begin{array}{l}19.16 \\
19.08 \\
19.11 \\
19.17 \\
19.07 \\
19.10 \\
19.10 \\
19.04 \\
19.08 \\
19.11\end{array}$ & $\begin{array}{l}2.988 \\
2.980 \\
2.985 \\
2.982 \\
2.989 \\
2.982 \\
2.988 \\
2.984 \\
2.982 \\
2.978\end{array}$ & $\begin{array}{l}0.1754 \\
0.1753 \\
0.1757 \\
0.1750 \\
0.1755 \\
0.1751 \\
0.1757 \\
0.1755 \\
0.1751 \\
0.1751\end{array}$ & $\begin{array}{c}2.00 \\
1.82 \\
- \\
- \\
- \\
- \\
- \\
- \\
- \\
-\end{array}$ \\
\hline $\begin{array}{l}10 \mathrm{a} \\
10 \mathrm{~b}\end{array}$ & 170.9 & $\begin{array}{l}0.2291 \\
0.2284\end{array}$ & $\begin{array}{l}76.15 \\
76.13\end{array}$ & $\begin{array}{l}19.10 \\
19.11\end{array}$ & $\begin{array}{l}2.971 \\
2.976\end{array}$ & $\begin{array}{l}0.1741 \\
0.1745\end{array}$ & $\begin{array}{l}1.23 \\
1.23\end{array}$ \\
\hline $\begin{array}{l}11 a \\
11 b\end{array}$ & 157.5 & $\begin{array}{l}0.2291 \\
0.2288\end{array}$ & $\begin{array}{l}76.23 \\
76.17\end{array}$ & $\begin{array}{l}19.00 \\
19.06\end{array}$ & $\begin{array}{l}2.983 \\
2.982\end{array}$ & $\begin{array}{l}0.1746 \\
0.1751\end{array}$ & $\begin{array}{l}1.33 \\
1.02\end{array}$ \\
\hline $\begin{array}{l}12 a \\
12 b\end{array}$ & 146.0 & $\begin{array}{l}0.2293 \\
0.2293\end{array}$ & $\begin{array}{l}76.14 \\
76.15\end{array}$ & $\begin{array}{l}19.09 \\
19.08\end{array}$ & $\begin{array}{l}2.985 \\
2.986\end{array}$ & $\begin{array}{l}0.1751 \\
0.1754\end{array}$ & $\begin{array}{l}1.16 \\
1.30\end{array}$ \\
\hline & & 0.2339 & 76.12 & 19.11 & 2.980 & 0.1755 & 1.57 \\
\hline \multicolumn{3}{|c|}{$\begin{array}{l}\text { Relative } \\
\text { standard deviation }= \pm 0.44 \%\end{array}$} & $\pm 0.065 \%$ & $\pm 0.26 \%$ & $\pm 0.23 \%$ & $\pm 0.38 \%$ & $\pm 26 \%$ \\
\hline
\end{tabular}

${ }^{a}$ The isotopic values for ${ }^{242} \mathrm{Pu}$ were not abtained by direct measurements but by subtracting the direst counting measurements of Table 7 from the differential transmission measurements of Table 6 . 


\section{Conclusions}

The overall results of these experiments are very encouraging. They demonstrate that plutonium concentration and isotopic measurements can be made to within 0.25 to $0.5 \%$. However, the results only indicate the applicability of the technique. Many more experiments must be made to investigate the effect of changing parameters held constant in these experiments, e.g., the isotopic abundances, and to Improve upon those parts of the experimental design or procedures that we know to be weak or not adequately understood.

For exdmple, we do not fully understand the slight nonlinear response in some of the data. One possible explanation is that the dilution procedures were not sufficiently accurate, or that evaporacion or temperature changes affected the concentration of the solution. Some credibility is given to this possibility by the fact that a 200microlitre portion of solution was removed :rom circulation toward the ere of the first experiment. Wher it was analyzed in the same way that the Initial starting solution was analyzed, we obtained a somewhat higher value of $176.9 \mathrm{~g} / 1 \mathrm{itre}$ as compared to a book value of $175.6 \mathrm{~g} / 1 \mathrm{itre}$. This evidence was not used to renormalize any data. However, it does indicate that the actual concentrations may indeed be different from those calculated from dilution factors.

Greiter attention must also be given to the proper way of measuring peak height ratios from the transmission experiments. Although we are confident that our methods of peak fitting are accurate, we need to study in greater detail the change in the intensity of the Compton continuum at the $\mathrm{K}$-shell binding energy of plutonium. An improper delineation of the continuum source under the peak doublet may be responsible for some of the nonlinearity in this measurement, particularly at the extremes of the range where the peak height ratio is quite different from 1 .

In future experiments we will also try to make independent measurements for each of the two gamma rays. This will reduce the problem in describing the background and eliminate the imbalance in peak height ratio at the extremes of the concentration range. However, it will require two separate counts for which we will need highly stable detector and counting systems.

other sources of nonlinearity in the direct measurement technique may be inaccuracies in the livetime correction or inaccurate algorithms used for making self-attenuation corrections. However, these possible 
sources of error have been carefully

checked and found to present no

obvious problems.

In general, the sizes of the cells and dimensions used in the experiment were approximately correct. However, the count rate experienced in measuring the chemically separated plutonium solution in the first experiment was initially too high. Therefore the distance between the detector and the cell was increased from about $0.5 \mathrm{~cm}$ to about $1.5 \mathrm{~cm}$ to reduce the count rate to an acceptable level. Also, in future experiments of this type, it would be helpful to Increase the signal level of the two gamma rays in the transmission measurement. This can be done by increasing the source strength and by making a corresponding reduction in the area of the coilimating hole.

We belleve that the most difficult assay in our experiments is the quantitative measurement of the four plutonium isotope- observed by direct counting. Our principal reason for making the measurements rigorously quantitative is so that the ${ }^{242} \mathrm{Pu}$ isotopic content could be deduced from the difference between the direct isotopic counting and the differential transmission measurements. However, studies are in progress to develop algorithms which can compute the ${ }^{242} \mathrm{Pu}$ content based on isotopic correlation techniques. 11 If this approach is successful, quantitative isotopic measurements w111 not be required and the measurement w111 be reduced to determining isotopic ratios, a measurement quite easily and accurately made by gamma spectrometry.

It therefore appears possible to perform a complete and quantitative In-line measurement for plutonium using a combination of techniques and methods that are nondestructive and can be automated. 


\section{References}

1. K. Gunnink and R. J. Morrow, Guma-Ray Energies ani Absolute Branching intersities for $238,239,240,247 \mathrm{Pu}$ and ${ }^{24 j} \mathrm{Am}$, Lawrence Livermore Laboratory, Rept, UCRL-51087 (1971).

2. J. E. Cline, Gomma Rays Emitted by the Fissionabie Nuclides and Associated lsotopes, Idaho Nuclear Corporation, Idaho Falls, Idaho, Rept. IN-1448 (1970) and ANCR-1069 (1972).

3. R. Gunnink, J. E. Evans, and A. L. Prindle, A Reevaluation of the Gamatrai, Energies and Absolute Branching Intensities of ${ }^{237} \mathrm{U}, 238,239,250,241 \mathrm{Pu}$, and $2 \hat{i}]_{A m}$, Lawrence Livermore Laboratory, Rept. UCRL-52139 (1976).

4. R. Gunnink, J. B. Niday, and P. D. Siemens, A System for Plutonium Analyses by Gamma Ray Spectrometry, Part 1: Techniques for Analysis of Solutions, Lawrence Livermore Laboratory, Rept. UCRL-51577 (1974).

5. D. L. Watkinson, Nuci. Instr. and Meth. 95, 259 (1971).

6. R. L. Roberts, R. A. Riddle, and G. T. Squire, Nucl, Instr. and Meth. 130,559 (1975).

7. R. Gunnink, An Algorithm for Fitting Lorenzian-Broadened, K-Series $X$-Ray Peaks of the Heavy E? ements, Lawrence Livermore Laboratory, Rept. UCRL-78707 (1976).

8. F. 0. Cartan, Allied Chemical Corporation, private commuication.

9. T. R. Canada, J. L. Parker, and T. 0. Reilly, "Total Plutonium and Uranium Determination by Gamma-Ray Densitometry," ANS Trans., 22, 140 (1975).

10. R. D. Baertach, "Surface Effects of P Type High Purity Germanium Detectors at 77K," IEEE Trans. Nucl. Sc. NS 21, 1 (1974).

11. D. Christianson, Battelle-Pacific Northwest Laboratory, Richland, Wash., private communication.

JTS/gw/vt 


\section{Appendix}

Plutonium Isotoplc concentrations can be assayed by direct counting of the gamma rays that are emitted by the solution. A problem arises, however, in detarmining the attenuation of the gamma rays in traversing a relatively thick sample vithout knowing a priori the plutonium concentration of the solution. We developed the following approximate solution to the problem using the intensities of the peaks representing the respective isotopes present, the respective absorption coefficients $\left(\mu_{1}\right)$ and the counting efficiencies $\left(\varepsilon_{1}\right)$ corresponding to a plutonium concentration approaching zero. Ignoring geometric considerations, we can express the observed counting activicy as follows:

$$
\begin{aligned}
\text { Activity }(A) & =\varepsilon \int_{0}^{x} \exp (-\mu \ell) d \ell \\
(A) & =\varepsilon / \mu[1-\exp (-\mu X)]
\end{aligned}
$$

where $X=$ amount of plutonium present. The true total activity, $A^{\circ}$, is given by

$$
\mathbf{A}^{\circ}=\varepsilon \mathbf{X} \text {. }
$$

Therefore,

$$
A / A^{0}=(1 / \mu X)[1-\exp (-\mu X)]
$$

or

$$
A^{\circ}=A \mu X /[1-\exp (-\mu X)]
$$

The total concentration of plutonium is simply the sum of the isotopic components, hence,

$$
x=\sum_{i=1}^{n} x_{1}=\sum_{i=1}^{n} \frac{A_{1}^{0}}{\varepsilon_{i}}
$$

Substituting Eq. 5, we obtain

$$
x=\sum_{i=1}^{n}: \frac{A_{1} \mu_{1} X}{E_{1}\left[1-\exp \left(-\mu_{1} X\right)\right]}
$$


11

$$
l=\sum_{i=1}^{n} i_{i}\left[1-\frac{A_{i} i}{\exp (-1, i x)]}\right.
$$

We now assume that one of the components, hence one term in Eq (B), is dominant and therefore ic..late it from the ocher cerms. For example,

$$
1=\frac{A_{1}^{\prime \prime} 1}{\left.t_{1}\left[1-\exp _{1} x\right)\right]}+\sum_{i=2}^{A} \frac{A_{f} j}{c_{1}\left[1-\exp \left(-\mu_{1} x\right)\right]} .
$$

Solving for $x$, we derive

$$
x=-\frac{1}{1} \ln \left[1-\sum_{1=1}^{n} \frac{\Lambda_{1} \mu_{1}}{\varepsilon_{1}} \frac{1-\exp \left(-\mu_{1} x\right)}{1-\exp \left(-\mu_{1} x\right)}\right] .
$$

The solution uf this equation requires an injtial estimate of the plutonium concentration, $x$, that can be used in the exponential terms in the righthand portion of the equation. We estimate this concentration by assuming chat $\omega_{i}=w_{1}$. Then

$$
X(\text { estimated })=-\frac{1}{\mu_{1}} \cdot n\left(1-\dot{H}_{1} \sum \frac{A_{i}}{\varepsilon_{1}}\right) .
$$

After summing the $A_{i} / E_{i}$ values, an initial estimate for $X$ can be used in Eq. (10). The $f$ inal value of $X$ is then calculated usirig Eq. (10). 